\title{
ÇALIŞMA HAYATINA ESNEKLİK SAĞLAYAN DÜZENLEMELER ÜZERİNE BİR DEĞERLENDİRME
}

\author{
Berna Yazar Aslan ${ }^{1}$
}

10RCID ID: http://orcid.org/ 0000-0001-7040-0104

\section{ÖZ}

Küreselleşme, bilgi teknolojilerindeki gelişim, hizmet sektörünün yükselişi, demografik değişimler, ekonomik krizler çalışan ve işveren iliş̧kilerinde önemli değişiklikler yaşanmasına neden olmuştur. Bu değişimler çalışma sürelerini ve biçimlerini, yeni teknolojilerin kullanımını ve işgücünün yapısını doğrudan etkileyerek çalışma ilişkilerinde esneklik dönemini başlatmıştır. İşci ve işletmenin birlikte korunması anlayıșının benimsendiği bu esneklik döneminde esnek çalışma olarak adlandırılan düzenlemeler ortaya çıkmıştır. İç ve dış sayısal, fonksiyonel, ücret esnekliği ve uzaklaştırma stratejileri olarak beş gruba ayrılan esneklik bu çalışmada istihdam biçimleri, çalışma süreleri ve iș ve aile yaşamını uyumlaştırma politikaları bağlamında üç başlık altında ele alınmaktadır. Çalışan profili, işletme, endüstri ve ülke koşullarına bağlı olarak kullanılan esnek çalışma düzenlemesinin çalışma koşulları üzerinde önemli etkileri bulunmaktadır. Bu çalışma, esnek çalışma düzenlemelerinin COVID-19 ile artan önemine dair bir değerlendirme amacı taşımaktadır. Esnek çalışma tanım, içerik, uygulama, avantaj ve dezavantajları başlıklarında analiz edilerek, değișen işgücü piyasasında ve özellikle salgın gibi kriz durumlarında çalışanların haklarını ve üretim sürekliliğini sağlamak için bir perspektif ortaya koymaktadır.

Anahtar Kelimeler: Esnek çalışma, Çalışma süreleri esnekliği, İ̧s-aile yaşamı uyumu.

\section{Atıf için:}

Yazar-Aslan, B. (2021). İşgücü piyasasında esneklik ve esnek çalışma düzenlemeleri üzerine bir değerlendirme. HAK-IŞ Uluslararası Emek ve Toplum Dergisi, 10(27), 268-298.

\footnotetext{
* Bu makale Prof. Dr. Şenay AÇıKGÖZ danışmanlığında yürütülen Berna YAZAR ASLAN'ın "İşgücü Piyasası Düzenlemelerinin Ekonomi ve İşücü Piyasası Üzerine Etkisi: Panel Veri Analizi Uygulaması" başlıklı doktora tezinden türetilmiştir.

${ }^{1}$ Dr., Çalışma ve Sosyal Güvenlik Eğitim Uzmanı, Çalışma ve Sosyal Güvenlik Eğitim ve Araştırma Merkezi, Ankara/Türkiye

E-posta: berna.yazar@ailevecalisma.gov.tr
} 


\title{
AN ASSESSMENT ON FLEXIBLE WORKING ARRANGEMENTS FOR WORKING LIFE
}

\begin{abstract}
Globalization, development in information technologies, rise of the service sector, demographic changes, economic crises have caused significant changes in employee and employer relations. These changes have started a period of flexibility in working relationships by directly affecting working hours and styles, the use of new technologies and the structure of the workforce. In this flexibility period in which the understanding of protecting the worker and the enterprise was adopted together, arrangements called flexible working emerged. In this study, flexibility, which is divided into five groups as internal and external numerical, functional, wage flexibility and distancing strategies, is discussed in the context of employment styles, working periods and policies of balancing work and family life. Flexible working arrangement, which is used depending on the employee profile, business, industry, and country conditions, has significant effects on working conditions. This study is intended as an assessment of the increasing importance of flexible working regulation with COVID-19. Flexible working is analyzed under the titles of definition, content, application, advantages and disadvantages, and presents a perspective to ensure the rights of the labor force and production continuity in the changing labor market and especially in crisis situations such as epidemics.
\end{abstract}

Keywords: Flexible work, working time flexibility, work and family life balance 


\section{GíRiş}

Emek yoğun üretim modelinden makine yoğun üretim modeline geçilmesi ve makineleşmenin artmasıyla birlikte hız kazanan Fordist (kitlesel) üretim zaman içerisinde belirli bir doygunluğa ulaşmıș, tüketicilerin zevk ve tercihlerindeki değişim nedeniyle talepler ortaya çıkmıştır. Taleplerde oluşan birikim ile sistem tıkanmış ve 1929 yılında talep kaynaklı ekonomik kriz yaşanmıştır. Bu krizi çözüme ulaștırmak amacıyla yapılan düzenlemelerde sendikalar, işveren örgütleri ve devlet arasında görüş birliği olușmuştur. Ancak 1960'lı yıllara gelindiğinde ekonomik göstergelere de yansıyamaya başlayan Fordist üretim modelinin olumsuz etkisi 1970 ve 1973 yllarında yaşanan krizlerle birleşmiş ve modelin devamlılığını imkânsız hale gelmiştir.

Fordist üretimin çökmesi ile bilgi ve iletişim teknolojilerinin gelişimi, teknolojik yenilikler ve otomasyonun hız kazanması, küreselleșme ve demografik değişimler işgücü piyasalarında çalışma şekli, çalışma süresi ve işgücünde değişimi beraberinde getirmiştir. Aynı zamanda işletmelerin rekabet edebilirliğini de artıran bu değişimler daha fazla kâr elde etmek ve piyasada oluşan taleplere daha hızlı karşılık verebilmek için çalışanlar ile standart iş sözleşmeleri dışında sözleşmeler yapılmaya başlanmıştır (Kalleberg, 2000, s.342).

Standart iş düzenlemeleri yirminci yüzyllda sanayileşmiş birçok ülkede iş hukuku, toplu pazarlık ve sosyal güvenlik sistemlerinin geliştirildiği çerçevenin temellerinin yer aldığı bir norm olarak yer almaktaydı. 1970'lerin ortalarından itibaren başlayan değişiklikler, ülkeler, sendikalar ve işçilerin istihdamda daha fazla esneklik arayışına sebep olan koşullar oluşturmuş ve standart olmayan istihdam ilişkisi ortaya çıkmıştır. Ekonomik büyümelerdeki yavaşlama, Avrupa ekonomilerinde tam zamanlı ücretli istihdam oluşturacak yeterli iş üretilememesi nedeniyle yükselen işsizlik oranları da standart dışı çalışmalara olan ilgiyi artırmıştır. Çalışma ilişkilerinde esneklik dönemi olarak ifade edilen bu süreç içerisinde standart istihdam ilişkisinde sorunlar yaşanırken standart dışı istihdam ilişkileri olarak da adlandırılan yeni esnek çalışma düzenlemelerinin ve uygulamalarının yaygınlaşması hız kazanmıştır (Jain ve Hassard, 2014).

Çalışanların ve işverenlerin işgücü piyasasında oluşan değişimlere karşı çalışma şartlarını düzenleyebilme imkânı sağlayan bu dönem içerisinde çalışanı işverene karşı koruma anlayışından vazgeçilerek çalışanın ve işverenin birlikte korunması anlayışı benimsenmiștir. Bu anlayışla birlikte istihdam kurallarında ve düzenlemelerinde kısıtlayıcı uygulamaların bulunup bulunmadığını, bu uygulamaların kaldırılması ve/veya yer alması durumunda işgücü arz ve talebi arasında daha iyi bir denge oluşup oluşmayacağı, istihdam ilişkilerinde aşınma ve/veya işgücü piyasalarında bölümlenme oluşturup olușturmayacağı politika yapıcıların ve araştırmacıların ilgi odağı haline gelmiştir.

Esnek çalışma türleri ile istihdamda yer alma çalışan açısından bir seçimdir ve işgücü piyasasına ilk defa giriş yapılması, deneyim eksikliği, iş arama ve istihdam firsatları konusunda yeterli bilgiye sahip olmama, beklentilerinin netleşme- 
mesi, dezavantajlı grupların işgücü piyasasına katılması, iş ve aile yaşamı arasında denge sağlaması bakımından olumlu sonuçları bulunmaktadır. Ancak standart istihdama göre daha düşük iş güvencesi ve sosyal güvenceye sahip olması ve ayrıca görece daha düşük ücret seviyeleri gibi olumsuz sonuçları da bulunmaktadır (Yazar Aslan, 2019, s.46).

Bu çalışma ile işgücü piyasasında yaşanan Covid-19 salgını ile daha çok öne çıkan esnek çalışma ve işgücü piyasasında karşılık bulduğu uygulamaların sağladığı avantajlar ve ortaya çıkan sorunlar olmak üzere esnek çalışma modelinin genel bir değerlendirmesi yapılmıştır. Bu değerlendirmede esnek çalışmaya dair mevcut ulusal ve uluslararası kaynaklar tanım, içerik, avantaj ve dezavantaj olmak üzere detaylı bir şekilde dört bölüm altında ele alınmıştır. Çalışmanın ilk bölümünde esneklik tanımı ve türleri açıklanmış, ikinci bölümde literatürde bilinen ve en sık şekilde uygulanan esnek çalışma türleri ve istatistiklerine yer verilmiştir. Üçüncü bölümde esnek çalışma düzenlemelerin sağladığı avantaj ve dezavantajlar ele alınmış ve sonuç bölümünde ise genel bir değerlendirme yapılarak konu ile ilgili önerilerde bulunulmuştur.

\section{Esneklik}

İşgücü piyasasında esnekleşme istihdam kuralları ve düzenlemelerine ait koruyucu hükümlerin katı olup olmadığını ve bu hükümlerin kaldırılması durumunda işgücü arz ve talebi arasında sağlanacak olan yeni dengenin daha olumlu sonuçlar doğurup doğurmayacağını ele alan bir süreçtir (Blanpain vd, 2006, s.1). Literatürde esneklik birçok araştırmacı tarafından hem işveren hem de çalışan açısından işgücü piyasasındaki değişimlere yanıt verebilme (istihdam, çalışma süreleri, ücret vb.) ve uyum sağlama yeteneği olarak tanımlanmıştır (Rodgers, 2007, s.2; Cazes ve Nesperova, 2007, s.1; Standing, 1999, s.30; Pollerts, 1988, s.283). Çalışmaları belirli kurallar ve yasaların koruması ve düzenlemesi altında olan çalışanların istihdam şekillerinde hem çalışanın hem işverenin ihtiyaçlarını gözeterek hukuki araçlarla düzenleme yapılabilmesine imkân sağlayan bir sistem olarak da nitelendirilmektedir (Ekonomi 1994, s.60).

İşletmeler bakımdan esneklik piyasalarda küreselleşme ile birlikte oluşan ekonomik ve sosyal değişimlere rekabet edebilirlik ve yine kendini devamlı yenileyen teknoloji doğrultusunda uyum sağlama yeteneğini artırmak için çalışma koşulları ve türlerini belirleyebilme serbestliği (TISK, 1994, s.9) olarak tanımlanırken çalışanlar bakımından ise yaşam sürecinde ortaya çıkan istek ve ihtiyaçlarına göre çalışma şartları, zamanı ve mekânı hakkında karar verici olarak uyum sağlayabilmesi olarak açıklanmaktadır (Taşoğlu ve Limoncuoğlu, 2010, s.77). Nihayetinde esnek çalışma geleneksel çalışma modellerinin dışında kalan tüm çalışma şekillerini içeren kapsayıcı bir kavramdır (Selby vd; 2001, s.3). 


\section{Esneklik Türleri}

İşücü piyasasında esnekliğe yönelik en geniş sınıflandırmada dış sayısal, iç sayısal, fonksiyonel ve ücret esnekliği olmak üzere beş çeşit esneklik türü bulunmaktadır (bkz. Tangian, 2006; Wilthagen ve Tros, 2004). Yapılan ișe, organizasyona ve sektörlere göre değişkenlik göstermekle birlikte literatürde en sık atıf alan esneklik türleri dış sayısal esneklik, iç sayısal esneklik, fonksiyonel işsizlik, ücret esnekliği ve uzaklaştırma stratejileridir.

Dış Sayısal Esneklik ile işletmelere değissen ekonomik koşullar ve üretim teknolojilerinde ortaya çıkan yeniliklere bağlı olarak piyasa şartlarındaki değişimlere karşı istihdam ettiği işgücü sayısında ihtiyacı doğrultusunda müdahalede bulunabilme serbestliği sağlanmaktadır. İç Sayısal Esneklik ile işverenleri işgücü sayısında azaltma yapılmaksızın çalışma saatleri, günü ve süresinde değişiklik yapabilme serbestliği bulunmaktadır (True, 1992, s.502). Fonksiyonel esneklik, işveren tarafından istihdam edilen işgücünün işyerinin farklı bölümlerinde çalışabilme, çalışma konusu ve içeriğinde değişiklik yapılabilme ve farklı görevleri üstlenebilme esnekliğine sahip olması iken (Eryiğit, 2011, s.10), Ücret esnekliği ile değişen işgücü piyasası koşulları karşısında ücret politikalarında ve seviyelerinde işverenlere düzenleme yapabilme serbestliği tanınmaktadır (True, 1992, s.505). Son olarak Uzaklaştırma Stratejileriyle, işletmedeki yürütülen bazı işlerin ya da üretimin işletme dışında başka işyerlerinde veya işletme içinde çeşitli amaçlarla başka işverene ait çalışanlar tarafından yerine getirilebilmektedir (Tuncay, 1995, s.274).

\section{Esnek Çalışma Düzenlemeleri}

Literatürde standart dışı çalışma veya atipik çalışma olarak da adlandırılan esnek çalışma bağımlı ve iki taraflı bir iş iliş̧isinin yanı sıra tam zamanlı ve belirsiz süreli olarak algılanan standart çalışma kapsamının dışında kalan her türlü çalışma olarak tanımlanmaktadır. Bu nedenle standart istihdam ilişkisinden sapan farklı iş sözleşmeleri biçimlerini bir araya getiren şemsiye bir terimdir. Esnek çalışma küreselleşme, bilgi ve iletişim teknolojilerindeki yeniliklerin ve demografik değişimin işgücü piyasasına yansıması olup dünya genelinde piyasalarının çağdaş bir özelliği haline gelmiştir. Ayrıca son on yll içinde sanayileşmiş ve gelişmekte olan ülkelerde önemi artmış, ekonomi ve iş dünyasında ise kullanımı gittikçe yaygınlaşmıştır (ILO, 2016:7). İşgücü piyasalarının kendine özgü koşullarına göre her ülkede farklı esnek çalışma türleri ve uygulamalarının öne çıkması nedeniyle bu bölümde literatürde bilinen ve en sik şekilde uygulanan esnek çalışma türleri ve istatistikler yer almaktadır. 


\section{Çalışma Süreleri Bakımından Esnek Çalışma Düzenlemeleri}

Çalışma sürelerine yönelik esneklik düzenlemeleri, hem işletmelerin gereksinimleri hem de çalışanların aile sorumlulukları da dâhil olmak üzere bireysel ihtiyaçları doğrultusunda çalışma sürelerinde ayarlama yapabilme olanağı sunmaktadır. İşletmelere ihtiyaç halinde normal çalışma saati dışında işgücü çalıştırma, çalışanlara ise işe başlangıç ve bitiş süresinin kendisi tarafından belirlenebilme serbestliği sağlamaktadır. Kısmi süreli çalışma, çağrı üzerine çalışma, yoğunlaştırışmış çalışma haftası, esnek zamanlı çalışma, çalışma sürelerinin yıllık ve ortalama saat olarak hesaplanması, vardiyalı çalışma, gece çalışması, hafta sonu çalışma ve fazla mesai uygulamada sıklıkla kullanılan çalışma sürelerine yönelik uygulanan esnek çalışma düzenlemeleridir.

Kısmi Süreli Çalışma: Esnek çalışma türleri içerisinde uygulamada en sık kullanılan kısmi süreli çalışmada çalışma süresinin uzunluğuna odaklanılmaktadır. Tam zamanlı çalışanlara kıyasla çalışma saatinin daha az olduğu, düzenli ve gönüllü olarak yapıldığı çalışmalardır (Limoncuoğlu, 2011, s.13; Tokol, 2011, s.127; Koç ve Görücü, 2011, s.150). Kısmi süreli çalışmada aranan temel özellikler süre, düzenlilik, süreklilik ve gönüllülüktür. Süre ile temel alınacak veya karşılaştırma yapılacak zaman dilimi ifade edilirken, düzenlilik ile kısa sürelerle çalışma ve belirli süreli çalışmadan, süreklilik ile geçici ve mevsimlik çalışmadan ayrılmaktadır. Gönüllülük ise işveren ve çalışanın özgür iradelerine dayanmayı ifade etmekte ve kısa süreli çalışma ve eksik istihdamdan ayırmaktadır (Centel, 1992, s.29-31).

175 sayılı ILO Sözleşmesi ve 1997 yllı 97/81/EC Avrupa Konsey Direktifi kısmi süreli çalışmaya ilişkin uluslararası belgelerdendir. Direktifte "Kısmi Süreli Çalışan" terimi normal çalışma süresi ortalama haftalık veya yıllık çalışma süresi olarak hesaplanan bir normal çalışma süresi ile tam zamanlı emsal çalışana göre daha az olan kişidir (M.3/1). "Tam zamanlı emsal çalışan" ise aynı işyerinde kıdem yeterlilik/beceri gibi diğer hususları da kapsayan ayn/benzer iş sözleşmesiyle veya çalışma ilişkisiyle aynı/benzer bir işte/meslekte çalışan tam süreli çalışandır (M.3/2). Aynı çalışma ortamında benzer tam zamanlı bir çalışan bulunmaması durumunda toplu sözleşmeye veya uygulamaya, toplu sözleşme bulunmadığı durumlarda ise ulusal yasalara ve toplu sözleşme uygulamalarına uygun olarak yapılacağı belirtilmiştir (EUC, 1997).

Kimi ülkeler kısmi süreli çalışma için ILO yasal kısmi süreli çalışma tanımını kullanırken maksimum çalışma saati veya asgari saat belirleyen ülkeler de bulunmaktadır. Tablo 3.1'de kısmi süreli çalışma tanımı için bazı ülkeler tarafından kullanılan eşik değer örnekleri yer almaktadır. 
Tablo 3.1. Kısmi Süreli Çalışma Tanımlamasında Kullanılan Eşik Değer

\begin{tabular}{ll}
\hline Ülke & Eşik Değer (saat) \\
\hline Finlandiya, Kanada, Yeni Zelanda, Türkiye, İngiltere, & $\mathbf{3 0}$ \\
Avustralya, Avusturya, İzlanda, Japonya, İsveç, ABD, Fransa, Meksika, Hol- & $\mathbf{3 5}$ \\
landa, & 36 \\
Macaristan & $\mathbf{3 7}$ \\
Norveç & $\mathbf{3 8}$ \\
Almanya, Hollanda, İrlanda, Lüksemburg & $\mathbf{4 0}$ \\
Polonya
\end{tabular}

Not: İtalya: Yaygın uygulama haftanın 5 günü ve toplam 38-40 saat çallşma süresi olarak belirlenmiștir. İspanya: Standart çalışma saatlerinin 2/3'ünden az olan veya bir yll, bir ay, bir hafta içinde belirlenen günlerde yapılan çalıșmadır. Çekya: Bir ya da dört haftalık bir azami zaman dilimi içinde normal çalıșma süresini aşmayan çalışmadır.

Kaynak: Bastelaer, Lemaitre ve Marianna 1997, s. 16-18; Kalleberg, 2000, s.343; ILO, 2004, s. 1; Yalçınkaya, 2006, 30-35.

Kısmi süreli çalışma kapsamında uluslararası istatistiki karşılaştırmalar yapılabilmesi için genellikle belirli süre çalışma saati kullanılır. Tam zamanlı ve kısmi süreli çalışmayı birbirinden ayıran eşik değer, ülkeler arasında farklılık göstermekte ancak genellikle haftada 30 veya 35 saat kullanılmaktadır. Ekonomik İș birliği ve Kalkınma Örgütü (OECD) 30 saat ve altında kalan çalışma süresini benimsemektedir. Grafik 3.1 OECD ülkelerinde 2019 yllına ait kısmi süre çalışma oranlarını göstermektedir.

\section{Grafik 3.1. OECD Ülkelerinde Kısmi Süreli Çalışma Oranları, 2019}

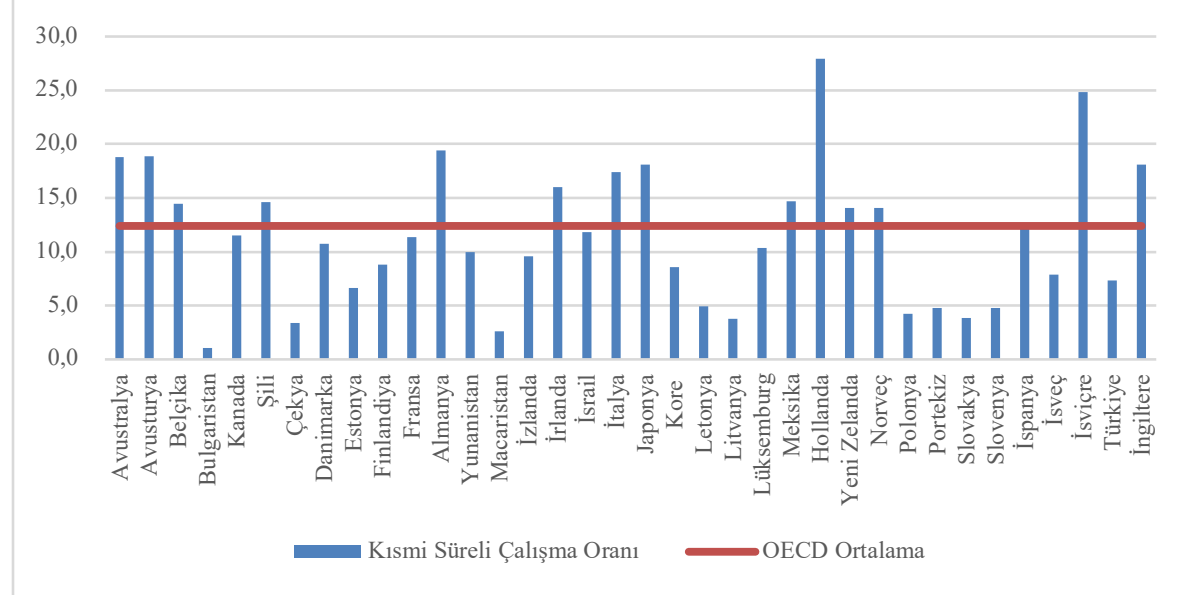

Kaynak: OECD, 2020. [http://stats.oecd.org/, Erişim Tarihi: 12.12.2020]

Kısmi süreli çalışma birçok ülkede işgücü piyasasında esneklik sağlama, iş ve aile uyumunu gerçekleștirme, istihdamı artırma ve işsizliği azaltma amaçlarıyla kullanılmaktadır. Grafik 3.1'e göre kısmi süreli çalışmanın en yaygın olduğu ve kısmen işverenlerin çalışanın isteği üzerine yasal olarak kısmi süreli sözleşme yapma yükümlülügü bulunduğu Hollanda \%28 oranı ile ilk sırada gelmektedir. Hollanda'yı \%24,8 ile İsviçre ve \%19,4 ile Almanya 
takip etmektedir. Bulgaristan ise \%1 ile en düşük kısmi süreli çalışma oranına sahip ülkedir.

Kısmi süreli çalışma oranlarındaki farklılıklar ülke uygulamaları, kültürel değerler, davranışlar ile iş ve aile yaşamı politikalarına bağlı olarak değişmektedir. Danimarka'da çalışan ailelerinin hem iş hem de aile yaşamlarını kolaylaştırma geleneği bulunurken (Gash, 2008, s.8), İtalya'da bu tür gelenekler bulunmamaktadır (Del Boca, 2002:3). Ayrıca kısmi süreli istihdam oranları güçlü ekonomik baskılar ve çocuk bakım maliyetleri nedeniyle de yükselmektedir. İngiltere'de kısmi süreli çalışma genellikle kısıtlanma olarak algılanmakta ve özellikle düşük ve orta gelir seviyesindeki kadınlar tarafından düşük ücretli ve vasıflı işlerde kullanılmaktadır (Alakeson, 2012, s.1) Bulgaristan'da ise saatlik ücret diğer ülkelere göre daha düşük olması nedeniyle yeterince kârlı bulunmamakta ve tercih edilmemektedir (Tomev, 2009; Miani ve Hoorens, 2014, s.12). Kısmi süreli çalışma oranları sanayileşmiş ülkelerde özellikle kadınlar arasında daha yüksektir. Ayrıca birçok ülkede özellikle hizmet sektörlerinde ve düşük vasıflı çalışanlar arasında daha yüksek kısmi süreli çalışma oranlarına rastlanılmaktadır (ILO, 2004).

Kısmi süreli çalışma uygulamaları işgücü piyasalarında iş paylaşımı, kademeli emeklilik ve kısmi süreli ebeveyn izni uygulamaları gibi özel türlere sahiptir. İş paylaşımı genel ekonomik görünümde meydana gelen dalgalanmalarda istihdamın korunmasını sağlamak amacıyla uygulanmaktadır. İş paylaşımı tam zamanlı bir işin görev ve sorumluluklarını (iş yükü, karar alma, problem çözme, sosyal hak vb.) birlikte üstlenen iki ya da daha fazla sayıda çalışanın işveren ile anlaşarak çalışma saatlerini kendi aralarında gönüllü olarak paylaşması ile oluşan düzenleme şeklidir. Tam zamanlı çalışanların ekonomik kriz zamanlarında "iş paylaşımı" programı uygulaması bu çalışanları yasal olarak kısmi süreli çalışan kategorisi kapsamına almamaktadır, ancak işsizlikten etkilenen tam zamanlı çalışan olarak değerlendirilmektedir. Buna rağmen, iş paylaşımı istatistikleri kısmi süreli istihdam ilgili istatistiklerde yer almaktadır. En sık Almanya ve İngiltere'de kullanılan iş paylaşımı Avrupa'da oldukça yaygındır. Bu düzenleme genellikle aynı bilgi, beceri ve yetenek seviyesine sahip ekip çalışanları tarafından kullanılırken farklı iki meslek çalışanı arasında da gerçekleştirilen örnekler bulunmaktadır. Tüm iş paylaşımı çalışmalarında önemli olan faktörler uyumlu çalışma ve çalışma süresini tamamlamaktır (Eyck, 2003, s.21).

Emeklilik, yaşam döngüsünün yaşlılık kısmında yapısal bir kırılma (tam istihdamdan tam emekliliğe geçiş sürecinde) ile tanımlanır. Kademeli emeklilik ise ani bir geçişten ziyade işteki etkinliğin azaltılmasıyla oluşturulan geçiş sürecidir. Emekliliğe geçiş süreci işin ve çalışma sürelerinin dolayısıyla elde edilen ücretin azaltılması şekilde çeşitli formlarda olabilir. Kademeli, aşamalı ve kısmi süreli emeklilik tanımlamalarının hepsi bu bağlamda kullanılan farklı kavramlardır. Literatürde kademeli emeklilik, emeklilik yaşına yakın çalışanların çalışma saatlerinin aşamalı olarak azaltılarak piyasadan 
kademeli olarak geri çekilmesini tanımlayan genel bir terimdir (Kantarcı ve Van Soest 2008, s.113-117). Ancak emeklilik uygulamalarına karşılık birçok alternatif bulunması ve gelir bakımından cazip görülmemesi sınırlı uygulama alanı bulmasına neden olmuştur. Kısmi ebeveyn izni, genellikle annelik veya babalık izni sona erdikten sonra çocuğun bakımı için daha uzun bir izin süresi olup genellikle ebeveynlerden birinin veya her ikisinin de kullanabildiği bir izin türüdür.

Çağrı Üzerine Çalışma: Çağrı üzerine çalışma, değişken ve öngörülemeyen saatlerde (sıfır saatten tam zamanlı çalışmaya kadar) çalışma ile tanımlanmaktadır ve hem geçici hem de kısmi süreli çalışmalarla örtüşmektedir. İşveren ve çalışan arasında yapılan iş sözleşmesi işveren tarafından ihtiyaç duyulduğunda çağrılması durumunda çalışanın belirli zamanlarda görevini yerine getirmesi esasına dayanmaktadır (Stredwick ve Allis, 2002, s.45).

Çağrı üzerine çalışma kavramı farklı ülkelerde farklı anlamlara karşılık gelmektedir, ancak Güney Kıbrıs, Yunanistan, Letonya, Portekiz, Romanya ve İspanya gibi bazı ülkelerde tanımlanmamış veya pek bilinmemektedir. Avusturya, Çekya, Estonya, Finlandiya, Fransa, Macaristan, Litvanya, Polonya ve Slovakya gibi bazı ülkelerde çağrı üzerine çalışma normal işin ayrılmaz bir parçası olarak değerlendirilmektedir. Belçika, İtalya, Hollanda ve Norveç gibi diğer ülkelerde ise başlı başına istihdam veya iş sözleşmesi türü olarak yer bulmuştur. Belçika, Almanya, Norveç ve İngiltere'de ise çağrı üzerine çalışmayla ilgili yasal düzenlemeler bulunmaktadır. İtalya ve Hollanda'da mevzuat özellikle "tek başına" çağrı üzerine yapılan sözleşmeleri düzenlemektedir (Eurofound, 2007).

Avrupa ülkelerinde çağrı üzerine çalışma hakkındaki kapsamlı karşılaştırılabilir veriler 2004 yılı Avrupa İşgücü Anketi ile elde edilmiş ve bu veriler Avrupa genelinde çalışanların yaklaşık \%2,5'inin "çağrı üzerine" çalıştığını ortaya koymuştur. Grafik 3.2. 2004 yılı Avrupa ülkelerinde tüm çalışanlar içerisinde çağrı üzerine çalışan oranını göstermektedir.

\section{Grafik 3.2. Çağrı Üzerine Çalışma Oranı (\%), Avrupa, 2004.}

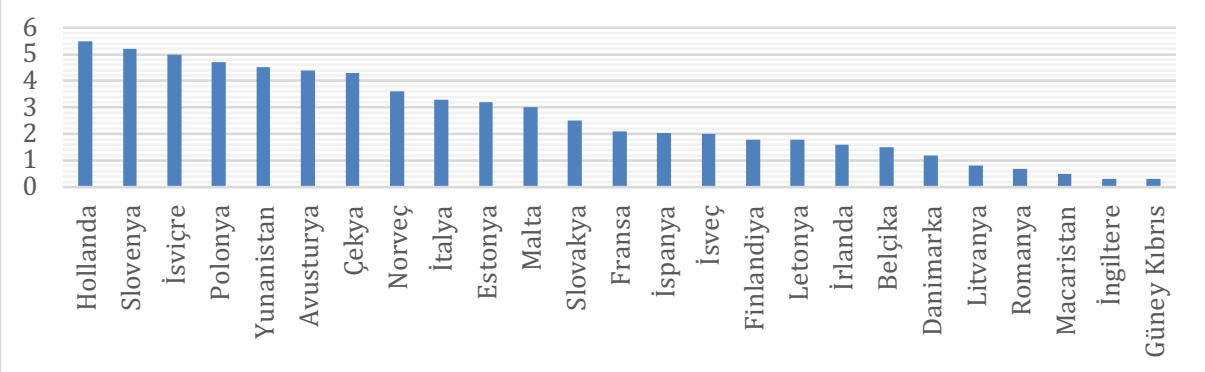

Kaynak: Eurostat, 2020, [https://ec.europa.eu/eurostat/web/lfs/data/database, Erişim Tarihi: 12.12.2020] 
Buna göre çağrı üzerine çalışma Hollanda ve Slovenya'da en yüksek, İngiltere ve Kıbrıs'ta en düşük seviyededir. Bu konudaki diğer çalışma ise 2010 yılında gerçekleştirilen Beşinci Avrupa Çalışma Koşulları anketidir ve elde edilen sonuçlara göre Birlik üyesi ülkelerde her beş çalışandan biri (\%21) çağrı üzerine çalışmaktadır. Erkekler (\%23) kadınlardan (\%16) daha sık çağrı üzerine çalışma yaparken çoğunlukla ulaşım (işçilerin\%30'u), inşaat (\%27), kamu yönetimi ve savunma (\%24), sağlık (\%25) ve tarım (\%23) alanlarında kullanılmaktadır (ILO, 2016, s.85).

Yoğunlaştırılmıs Çalışma Haftası: Yoğunlaştırılmış çalışma haftaları, standart haftalık çalışma süresinin daha az sayıda gün ancak toplamda aynı çalışma saati elde edilecek şekilde düzenleyen uygulama olup çalışma günü içinde daha uzun çalışma saatleri oluşturur. Genel olarak bir çalışma gününü sekiz saatin üzerine çıkarır ancak ardışık çalışılan gün sayısının bir haftada beş günden daha az olmasını sağlar. Uygulamada haftalık toplam çalışma süresinin yoğunlaştırılma yapılan işgünlerine eşit bir şekilde veya günlük çalışma süreleri arasında farklı şekilde dağıtılması gibi farklılıklar bulunmaktadır. Yoğunlaştırılmış çalışma haftası genellikle ofis ortamlarında işletme maliyetlerini azaltmak için kullanılmaktadır. Açık deniz petrol endüstrisi ve madencilik gibi evi ile işyerleri arasında uzun mesafeler bulunan işlerde çalışanlar için daha sıklıkla uygulanmaktadır (ILO, 2019, s.21)

Esnek Zamanlı Çalışma: Esnek zamanlı çalışma düzenlemeleri, çalışma saatlerinin günlük ve haftalık olarak esnek bir şekilde programlanmasına olanak tanır. Çalışanların gerçekte çalıştıkları saat sayısı günden güne ve haftadan haftaya değişebilir. Basit esnek zaman düzenlemeleri, çalışanların işe başlama ve bitirme için günlük çalışma sürelerini bireysel ihtiyaçlarına (belirli sınırlar dahilinde) ve hatta bazı durumlarda belirli bir haftada çalıştıkları saat sayısına göre seçmelerine imkân sağlar. Genel olarak, esnek zaman düzenlemeleri veya programları, tüm çalışanların işte olması gereken bir "temel çalışma saatleri" dönemi oluşturmayı gerektirir. İlk kez Alman havacılık sektöründe kullanılmış ve olumlu sonuçlar alınması üzerine 1969 yılından itibaren İsviçre, İsveç, Norveç, Danimarka, Finlandiya, İngiltere, İtalya, Fransa, ABD, Kanada ve Japonya'da uygulanmaktadır (ILO, 2019, s.25).

Çalışma Sürelerinin Yılık ve Ortalama Saat Olarak Hesaplanması: Yıllık olarak belirlenmiş saat ve diğer ortalama çalışma saati süreleri (bir aylık süre içerisinde ortalama saat) ile bir haftadan daha uzun süre boyunca günlük ve haftalık çalışma sürelerinde çeşitli değişiklikler yapılmasına izin verilir. $\mathrm{Bu}$ düzenlemeyle ya çalışma saatlerinin ortalaması alınan süre boyunca belirli bir haftalık ortalamaya ulaşılması ya da belirlenen süre içerisinde sabit bir toplamda kalması gerekmektedir. 
Bu düzenleme, yoğun sezonda daha uzun çalışma saatlerine ve diğer zamanlarda daha kısa çalışma saatlerine izin verilmesi nedeniyle talepte öngörülebilir mevsimsel değişikliklere sahip (örneğin kayak merkezleri) işletmelerde daha sıklıkla kullanılmaktadır. AB'nde yıllık olarak belirlenmiş çalışma saatleri ve benzer düzenlemelerin kullanımı oldukça yaygındır. Fransa'da çalışma saatlerinin yıllık hale getirilmesiyle birlikte 35 saatlik çalışma haftası uygulamaya konulmuş ve böylece normal saatlerde 35 saatlik sınır ylllık ortalama olarak kabul edilmiştir. Ylllık saat ve benzeri düzenlemeler, Danimarka ve Finlandiya da dâhil olmak üzere, İskandinav ülkelerinin çeşitli işletmelerinde de yaygın olarak kullanılmaktadır (ILO, 2011, s.52-53).

Vardiyalı Çalışma- Gece Çalışma- Hafta Sonu Çalışma: Vardiyalı çalışma bir işyerinde çalışanların farklı gün ve gece çalışma saatlerinde birbirlerinin çalışma sürelerini takip ederek çalışma yapabilmesine bir diğer değişle işletmenin günlük normal çalışma süresinin uzatılmasına olanak sağlayan çalışma sürelerini organize etme yöntemidir. Vardiyalı çalışma, işletmelerin çalışma saatlerinin uzatılmasına ve yoğun talep dönemlerinin daha iyi karşılamalarına olanak tanır. Vardiya sistemleri genel olarak iki temel kategoriye ayrılmaktadır. Bu kategorilerden ilki belirli bir çalışan grubunun her zaman aynı vardiyada çalışması; ikincisi ise çalışanların zaman içinde ve gün boyunca düzenli olarak değişen vardiyalara atandıkları çalışmadır. Yaygın olarak iki ve üç sabit vardiya sistemleri kullanılmaktadır. Vardiyalı çalışma ulusal ekonomilerin sektörel bileşimleri ile yakından ilişkilidir ve özellikle sağlık ve sosyal işler, oteller ve restoranlar, üretim ve ulaşım, depolama ve iletişim sektörlerinde yaygındır (ILO, 2011, s.43).

\section{Grafik 3.3. Vardiyalı Calışma Oranı, Avrupa, 2019}

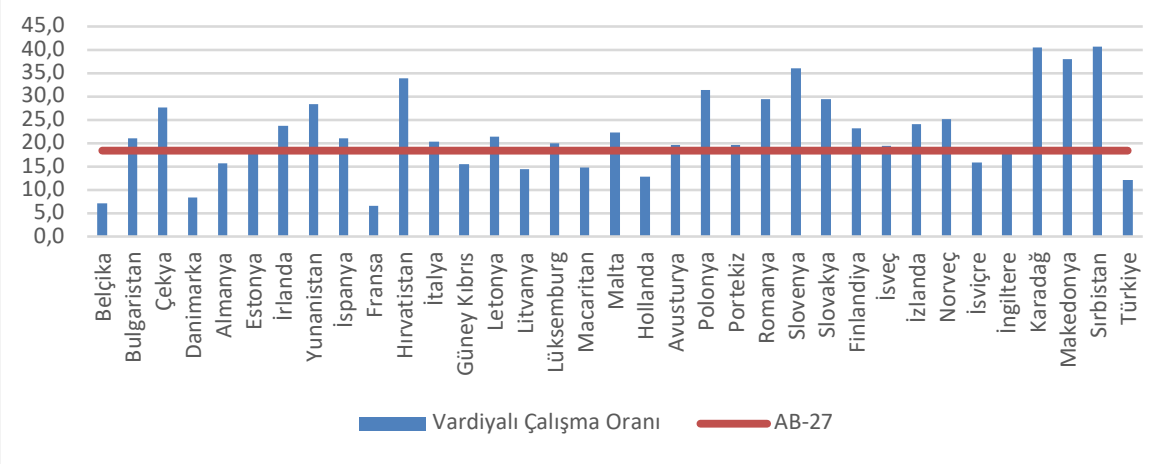

Kaynak: Eurostat, 2020. [https://appsso.eurostat.ec.europa.eu/, Erişim Tarihi: 12.12.2020]

Bir bütün olarak 2019 yllında AB'de çalışanların \%18,3'ü vardiyalı çalışma gerçekleştirmiştir. Grafik 3.3. en yoğun vardiyalı çalışmanın Sırbistan, 
Karadağ ve Slovenya'da gerçekleşirken Fransa, Belçika ve Danimarka vardiyalı çalışma düzenlemesinin en az kullanıldığı ülkelerdir. ABD Çalışma İstatistikleri Bürosu'na göre, 2018 yılında ücret ve maaşlı çalışanların yaklaşık $\% 16,4$ 'ü vardiyalı çalışma programlarına sahiptir ve en sık hizmet ve satış ile ilgili sektörlerde kullanılmaktadır (BLS, 2020). Avustralya Çalıșma İstatistikleri Bürosu 2019 yılında çalışanların \%15,6'sının, çoğunlukla madencilik, barınma ve yemek hizmetleri, sağlık hizmetleri ve sosyal yardım alanlarında vardiyalı çalıştığını belirtmektedir (ABS, 2020). Japonya'da, ise 2008 yılında çalışanların \%10,5'i vardiyalı çalışma sistemi altında çalışmaktadır (Ogura, 2010, s.97).

Gece çalışması standart çalışma haftası sınırları dışında çalışmalar, hafta sonu çalışması ise normal dinlenme günlerinde yapılan çalışmalardır. Gece çalışması hakkında 171 sayılı ILO Gece Çalışma Sözleşmesi ile bir dizi korumalar öngörülmüştür. 14 ve 106 sayılı ILO Haftalık Dinlenme Sözleşmeleri ise her işçinin yedi günde bir en az 24 saat kesintisiz dinlenmesi düzenlemesini içerir (ILO; 2019, s.15).

\section{Grafik 3.4. AB Ülkelerinde Gece Çalışma Oranı, 2019}

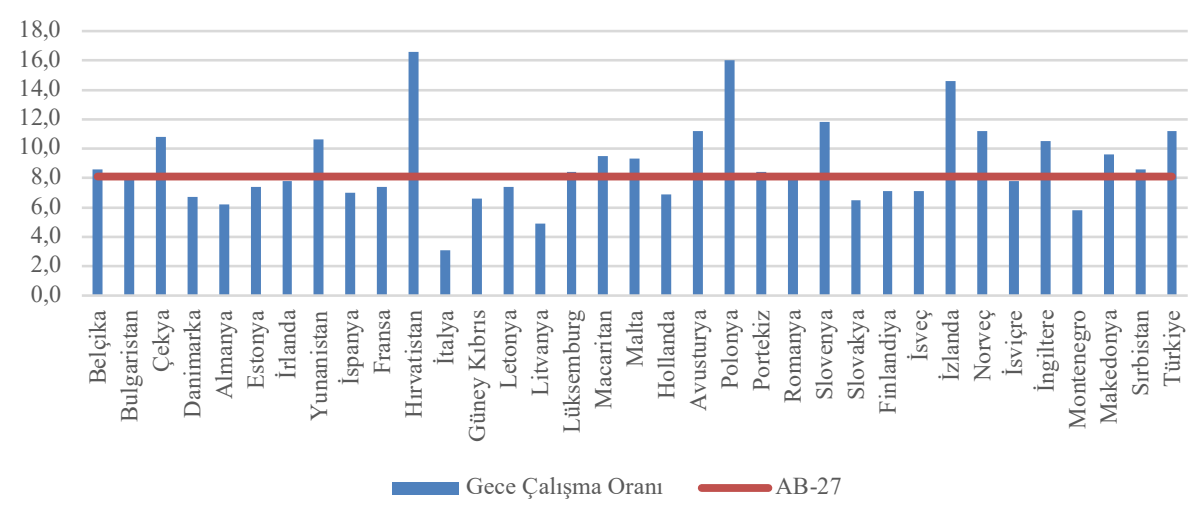

Kaynak: Eurostat, 2020. [https://appsso.eurostat.ec.europa.eu/, Erişim Tarihi: 12.12.2020]

Grafik 3.4'e göre 2019 yılında çalışanların \%8,1'i gece çalışması yapmakta ve en yaygın olarak Hirvatistan, Polonya ve İzlanda ve Slovenya'da kullanılmaktadır. "7/24 ekonomi" olarak adlandırılan ABD'de 2018 yılında çalışanların \%3,4'ü gece çalışmasını gerçekleştirmektedir (BLS, 2020).

Hafta sonu çalışmaları gece çalışmasına kıyasla daha yaygındır. Örneğin, Avrupa'da en yaygın olarak kullanılan standart dışı çalışma cumartesi günü çalışmadır. 2009 yılı Avrupa şirketler araştırmasına göre AB genelinde (aday ülkeler dahil) çalışanların $\% 40$ 'ı cumartesi günü, \%26'sı ise pazar günü çalışmaktadır. AB'de (aday ülkeler de dahil olmak üzere) hafta sonu çalışmaları 
en çok Letonya, Malta, Polonya, Türkiye ve İngiltere'de yaygındır ve gece çalışması sağlık, sosyal çalışmalar, oteller ve restoranlarda yoğundur (Riedmann, Gyes, Roman, Kerkhofs, Bechmann, 2010, s.20).

Fazla Mesai: Fazla mesai, günlük veya haftalık çalışma saatlerinin uzatılmasında kullanılan bir yöntemdir ve bir çalışmanın "fazla mesai" olarak değerlendirilip değerlendirilmeyeceği ulusal (veya yerel) iş kanunlarında tanımlanan yasal günlük ve/veya haftalık çalışma saatleri, sözleşmeye dayalı veya toplu olarak kararlaştırılan çalışma saatleri ile olağan çalışma saatlerine göre değişmektedir. Bu yasal düzenlemelerle fazla çalışma tanımını oluşturan eşik değerler tanımlanmakta ve uygulamalar ülkeden ülkeye farklılık göstermektedir. ILO Çalışma Saatleri (Sanayi) Sözleşmesi (No.1) ile uluslararası norm olarak maksimum normal çalışma süresi haftada 48 saat ve günde 8 saat olarak belirlenmiștir. İstisnai durumlarda, günlük ve haftalık maksimum sürelere uyulduğu sürece çalışma süresinin bu sınırları aşmasına izin verilmektedir.

Dünya genelinde, ulusal mevzuatlarla belirlenen azami haftalık çalışma saati sınırı bulunmayan sınırlı sayıda ülke bulunurken (\%16), ülkelerin büyük çoğunluğunun haftalık çalışma saatlerine (\%75) maksimum sınır koyan mevzuat bulunmaktadır (ILO, 2013, s.11). AB genelinde 2009 yılında tüm işletmelerin yaklaşık üçte ikisi ve bu işyerlerinde çalışanların neredeyse yarısı fazla mesai yapmıştır (Riedmann vd, 2010:11). Fransa, Almanya, İrlanda, Hollanda, İskandinav ülkeleri ve İngiltere gibi ülkelerdeki işletmelerin fazla mesai kullanma olasılığı daha yüksek iken Güney Avrupa'daki ülkeler (İtalya ve Malta hariç) ve Orta ve Doğu Avrupa'da (Çekya hariç) bu olasılık daha azdır. $\mathrm{AB}$ dışındaki gelişmiş ülkelerde de fazla mesai yaygın olarak kullanılmaktadır. Örneğin Avustralya'da çalışanların \%38'i fazla mesai yaparken Japonya'da çalışanların yüzde 54,2'si "çoğu kez" \%33,7'si ise "zaman zaman" fazla mesai yapmaktadır (ILO, 2011, s.44).

\section{İstihdam Biçimleri Bakımından Esnek Çalışma Düzenlemeleri}

İstihdam biçimleri bakımında esneklik düzenlemeleriyle esneklik arayışının işletme dışında olması durumu ifade edilmektedir. Yaşanan teknolojik gelişmelere ve bilgi iletişim ağının genişlemesine bağlı olarak bir takım işlerin yapılabilmesi işletmeye mekânsal olarak bağlılığı zorunluluk olmaktan çıkarmıştır. Ayrıca işletmeye ait bazı işlerin başka işyerlerinde veya işletme içinde çeşitli amaçlarla başka işverene ait çalışanlar tarafından yerine getirilebilmesine olanak sağlamaktadır. Uygulamada sıklıkla karşılaşılan bu tür esnek çalışma düzenlemelerinin başında tele çalışma, evde çalışma, belirli süreli çalışma, geçici çalışma ve ödünç iş ilişkisi ve özel istihdam büroları gelmektedir.

Tele Çalışma (Uzaktan Çalışma): Esnek çalışma türlerinden bilgi teknolojilerine bağlı olarak gelişen tele çalışma bir uzaklaştırma stratejisidir. İlk defa 
1970'li yıllarda yaşanan kriz sonrası enerji tüketiminin azaltılması için seyahatlerin sınırlandırılmasıyla ortaya çıkmıştır. Bilgi ve iletişim teknolojilerinde devamlı yaşanan gelişmeler ve internet kullanımının yaygınlaşması bu çalışma türünün gelişimine büyük katkı sağlamıștır (Dambrin, 2004, s.359). Organizasyon, mekân ve teknoloji olmak üzere üç temel kavram üzerinde yoğunlaşmakta ve yapılan tanımların birçoğu bu kavramlardan en az ikisinin birleşimine dayanmaktadır. Uzaktan çalışma ve yeni teknolojilerin çalışma hayatında kullanımı örgütsel bir değişim oluşturmaktadır. Bu nedenle ILO tarafından merkez büro veya üretim yapıldığı yerden uzak bir mekânda, çalışanların yeni teknolojiler kullanarak iletişim sağladığı çalışma şekli olarak tanımlanmıştır (Di Martino ve Wirth, 1990, s.530).

Tele çalışma ile ilgili ilk düzenleme 1996 tarihli 177 sayılı ILO Evde Çalışma Sözleşmesidir. Avrupa Birliği düzeyinde ise 2002 yılında Tele Çalışma Hakkında Avrupa Çerçeve Anlaşması imzalanarak bu çalışma türü ile ilgili temel kuralların büyük kısmı belirlenmiş ve bilgi teknolojileri kullanımıyla bir iş sözleşmesine bağlı olarak işverene ait işyerinde gerçekleştirilebilecek işlerin, işyeri dışında düzenli olarak yürütülmesi şeklinde tanımlanmıştır. Evde tele çalıșma, uydu büro, komşu büro ve mobil tele çalıșma olmak üzere dört alt türü bulunmaktadır (Di Martino ve Wirth, 1990, s.530).

\section{Grafik 3.5. AB Ülkelerinde BíT Kullanım Yoğunluk Seviyesi, 2005-2015}

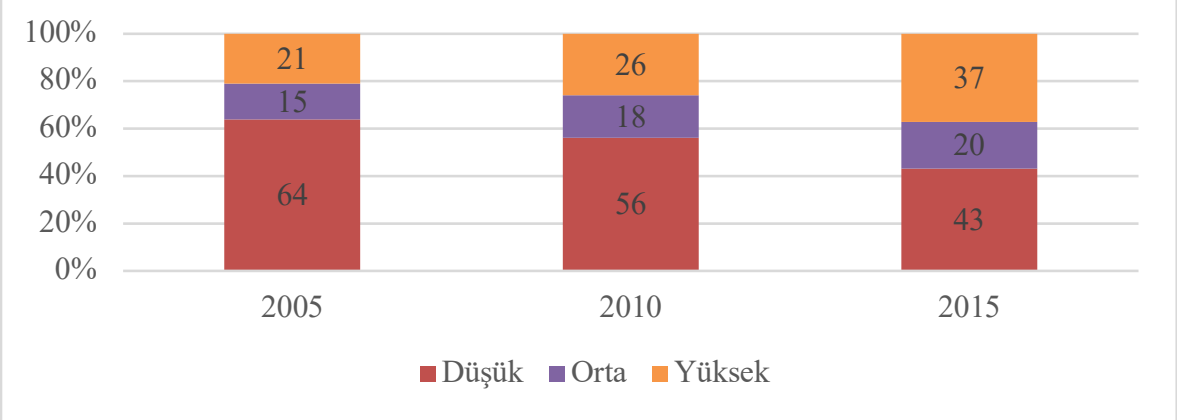

Kaynak: Altıncı Avrupa Yaşam Koşulları Anketi, Eurofound, 2017.

Grafik 3.5 2005-2015 döneminde AB ülkelerinde bilgi iletişim teknolojilerinin çalışanlar tarafından kullanım yoğunluk seviyesini göstermektedir. 2005 yılında yüksek oranda BíT kullanan çalışan oranı \%21 iken 2015 yllında \%37'ye yükseldiği düşük oranla BíT kullanan çalışan oranının ise \%64'ten 2015 yılında \%43'e gerilediği görülmektedir. 


\section{Grafik 3.6. AB Ülkelerinde BíT Kullanım Yoğunluğu, 2005-2015}

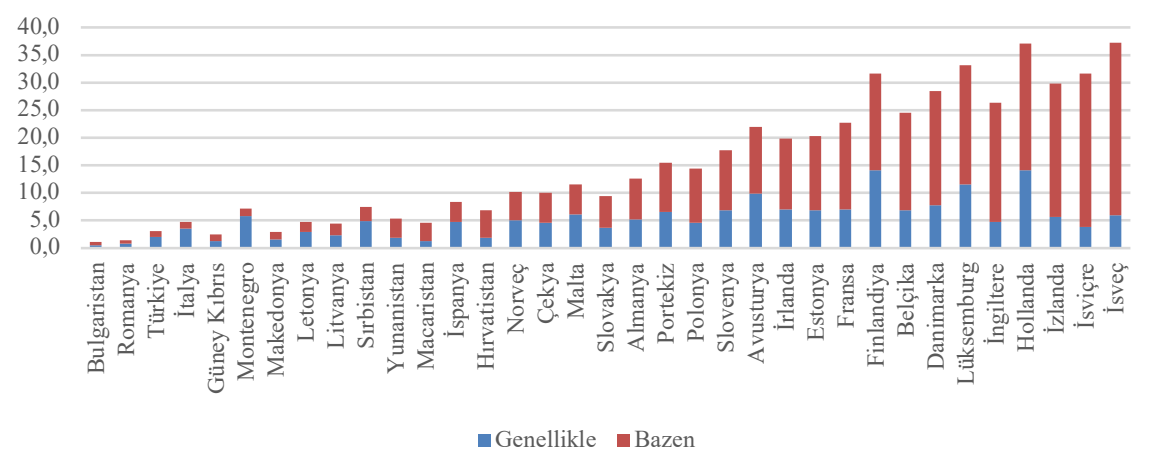

Kaynak: Eurostat, 2020. [https://appsso.eurostat.ec.europa.eu/, Erişim Tarihi: 12.12.2020]

Grafik 3.6'da 2019 yılına ait AB ülkelerinde bilgi iletişim teknolojilerinin çalışanlar tarafından kullanım yoğunluğu oranları yer almaktadır. İsveç, Finlandiya ve Hollanda da dahil olmak üzere bazı Avrupa Birliği ülkelerinde bilgi iletişim teknolojilerinin çalışanlar tarafından kullanım oranı \%30'un üzerindeyken, diğer birlik ülkelerinin yarısında \%10'un altında kalmıştır. Bu iki uç arasında Belçika, Fransa ve Portekiz gibi ülkelerde tele-çalışma oranı \%1524 arasında değişmektedir.

Bu çalışma türü eğitim, finans, bankacılık ve sigortacılık, basın yayın, haberleşme, ticaret, büro hizmetlerinde sıklıkla kullanılırken, mesleki açıdan yöneticiler, profesyonel, satış çalışanları, sosyal hizmetler, pratisyenler, finansal danışmanlar, mobil bakım mühendisleri ve çağrı merkezleri tarafından tercih edilmektedir (Eurofound, 2017, s.85-86).

Evde Çalışma: Genel olarak evde çalışma piyasaya yönelik üretilen mal ve hizmetlerin kişinin evinde gerçekleștirildiği çalışma şeklini ifade etmektedir (Karadeniz, 2004, s.26). ILO tarafından yapılan evde çalışma tanımı ise 1996 tarihli 177 sayılı Evde Çalışma Sözleşmesine dayanmaktadır. Bu sözleşme ile evde çalışanlar ile işyerinde çalışanlar arasında ayrım yapılamayacağından (eşitlik ilkesi) ve iş sağlığı ve güvenliği konusunda gerekli tedbirlerin alınmasının öneminden bahsedilmektedir. İlgili sözleşmede, "ev işi" terimi, bir kişinin (evden çalışan) (i) evinde veya kendi seçtiği başka bir yerde, işyeri dışındaki işyerinde yürüttügü; (ii) ücret karşılığında; (iii) kullanılan ekipmanı, malzemeleri veya diğer girdileri kimin sağladığına bakılmaksızın, işveren tarafından belirlenen bir ürün veya hizmetle sonuçlanan, kanunlar, yönetmelikler veya mahkeme kararlarına bağlı olarak ulusal düzeyde bağımsız bir işçi olarak kabul edilmesi için gerekli özerklik ve ekonomik bağımsızlık derecesine sahip olmayan çalışanlar tarafından yapılan iş olarak tanımlanır.

Evde çalışma farklı şekillerde geçekleştirilebilir. Örneğin evde bağımsız çalışanlar bir işverene bağımlı olmadan ne üreteceğine, ürettiği ürünü kime 
satacağına kendisi karar vermekte ve ilgili sorumluluklar kendisine ait olmaktadır (Emirmahmutoğlu, 2015, s.26). Ayrıca bir işverene bağlı olarak çalışan ve eve iş götüren ama yaptığı iş karşılığında ücret almayan kişiler "Eve İş Götürenler" olarak tanımlanmaktadır (Yavuz, 1995, s.58). Ancak bir evde günlük yaşayış içerisinde yürütülen hizmetlerle ev sahibi veya kiracının işinin görüldüğü ev hizmeti kapsamında yapılan çalışma evde çalışma ile karıştırılmamalıdır (Alp, 2012, s.40).

Avrupa Birliği ülkelerinde 2019 yılında evden çalışma oranları \%5,4 ve bazen evden çalışanların oranı \%9 ve genellikle evde çalışanların oranı ise \%36 olarak gerçekleşmiştir. Evde çalışma dokuma, hazır giyim, terzilik, yiyecek - içecek, çiçekçilik, el işi, paketleme gibi çok farklı ve çeşitli alanlarda gerçekleştirilebilmektedir. Ülkelerin kendi ulusal mevzuatlarında da evde çalışma ile ilgili farklı düzenlemeler bulunmaktadır. Örneğin Almanya, Küba, Arjantin, Japonya, Norveç ve İtalya evde çalışma ile ilgili özel bir yasa ile düzenlenme yaparken İsviçre, Fransa, Meksika, Panama ve İspanya'da genel yasalar içerisinde düzenlenmiştir (Tan, 2007, s.28).

Belirli Süreli Çalışma: Belirli süreli çalışma, bitişinin belirli bir tarihe, belirli bir sonucun ortaya çıkmasına veya özel bir görevin veya projenin tamamlanması gibi kesin koşullara açık bir şekilde bağlı olan istihdam düzenlemesidir. Belirli süreli çalışmalara yönelik uluslararası çalışma standartları ile doğrudan bir düzenlenme bulunmamakla birlikte 1999/70/ EC sayll Konsey Direktifi bu çalışma türünü düzenleyen en ayrıntılı belgedir. Direktif, "belirli süreli çalışan" terimini "işveren ve çalışan arasında doğrudan başlayan, sona ermesinin belirli bir tarihe ulaşma, belirli bir görevin tamamlanması veya belirli bir olayın ortaya çıkması gibi nesnel koşullarla belirlendiği bir istihdam sözleşmesine veya ilişkisine sahip kişi” olarak tanımlamaktadır.

\section{Grafik 3.7. AB Ülkelerinde Bir Yıldan Kısa Süreli Çalışma Oranları, 2019.}

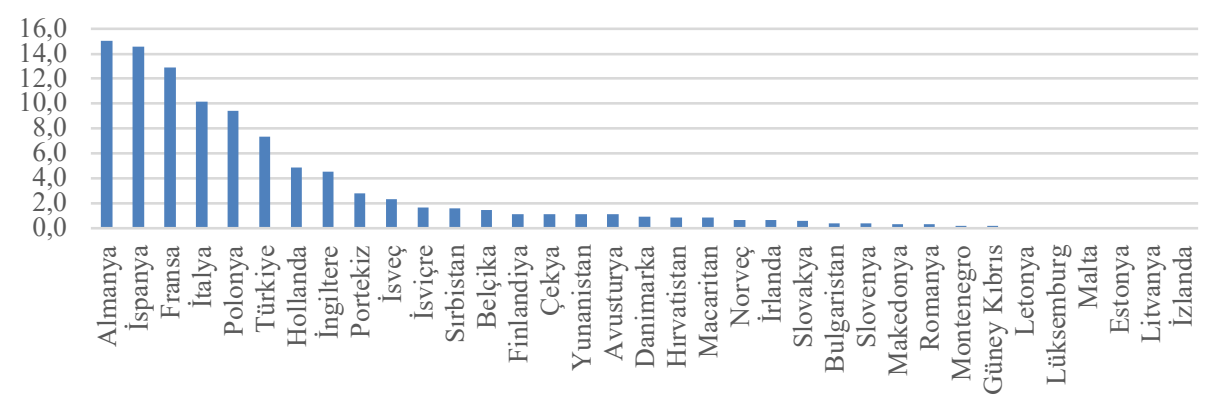

Kaynak: Eurostat, 2020. [https://appsso.eurostat.ec.europa.eu, Erişim Tarihi: 14.02.2021]

1980’li yıllardan 2000’li yıllara kadar geçen süre içerisinde İspanya, İtalya, Almanya ve diğer bazı ülkelerde istihdamı artırmak ve ekonomik bü- 
yümedeki yavaşlamanın getirdiği negatif istihdam etkisiyle mücadele edilmek amacıyla yasal değişiklikler yapılarak belirli süreli sözleşmelere öncelik verilmiștir. Özellikle Hollanda ve İtalya olmak üzere Avrupa ülkelerinde oldukça ilgi görmüştür. İspanya ve Portekiz gibi bazı ülkelerde önceleri gençlerin işgücü piyasasına girişiyle sınırlandırılırken yapılan düzenlemelerle diğer çalışanları da kapsayacak şekilde genişletilmiştir (ILO, 2016, s.57).

Grafik 3.72019 yılı AB ülkelerinde bir yıldan kısa süreli çalışma oranlarını göstermektedir. Buna göre bir yıldan kısa süreli çalışma oranının en yüksek olduğu ülkeler Almanya $(\% 15,1)$, İspanya $(\% 14,6)$ ve Fransa $(\% 12,9)$ iken Estonya, Litvanya ve İzlanda'da oranlar yok denecek kadar düşük seviyelerdedir.

Tablo 3.2. Belirli Süreli Çalıșma Yapılma Nedenleri, AB- 2019

\begin{tabular}{llll}
\hline & Kadın & Erkek & Toplam \\
\hline Kalıcı bir iş bulamama & 52,1 & 50 & 51,1 \\
Eğitim ve öğretim & 14,1 & 13,8 & 14 \\
Kalıcı bir iş̧ talep etmeme & 13,5 & 16,4 & 15 \\
Deneme süreli sözleșme yapma & 8,4 & 8,9 & 8,7 \\
Cevapsız & 11,8 & 10,9 & 11,3 \\
Toplam & 100 & 100 & 100 \\
\hline
\end{tabular}

Kaynak: Eurostat, 2020. [https://appsso.eurostat.ec.europa.eu, Erișim Tarihi: 12.12.2020]

Tablo 3.2'ye göre belirli süreli çalışmanın çalışanlar tarafından tercih edilmesindeki en büyük etken kalıcı bir iș bulamama sorunudur. Ayrıca veriler cinsiyete bağlı çarpıcı bir farklılık göstermemekte ancak kalıcı bir iş bulamadıkları için bu tür istihdam ilişkisi kullanan kadınların erkeklere göre biraz daha yüksek olduğunu göstermektedir.

Geçici Çalışma: Genel bir yasal tanımı bulunmayan geçici çalışma veya istihdam için bazı ortak unsurlar tanımlanabilmektedir. Bunlardan ilki geçiciliktir, işin doğası gereği çalışma geçici veya aralıklıdır. Bir diğeri ise ilgili çalışma faaliyetinin işverenin olağan veya kalıcı iş faaliyetinden ayrılması şartıdır. $\mathrm{Bu}$ unsurlar ikincil mevzuatlar, mahkemeler veya ulusal uygulamalarla belirlenmektedir. Geçici çalışma için oldukça yaygın kullanılan tanımlama, iş faaliyetinin işverenin daimî ya da sıradan iş faaliyetinden dışlanması gerekliliği ile maksimum süre şartının bileşiminden oluşmaktadır. Tüm bu bilgiler ışığında geçici çalışma, çok kısa bir süre boyunca veya ara sıra ve aralıklı olarak, genellikle belirli bir saat, gün veya hafta boyunca yürütülen çalışma olarak tanImlanabilmektedir (ILO, 2016, s.23).

Geçici çalışma, özellikle çocuk sahibi ebeveynler, bakmakla yükümlü olduğu bireyleri bulunan çalışanlar ve aynı zamanda eğitim/mesleki eğitim ile çalışma hayatını birleştirmek isteyenler için işgücüne katılımın alternatif bir yoludur. Dünyada sanayileşmiş ekonomilerde ve gelişmekte olan birçok ülkede geçici ve günlük işler açlkça tanımlanmış veya düzenlenmiştir. Danimarka, İtalya, Hollanda, ABD gibi ülkelerde işsiz kalmak yerine geçici bir işte çalışmak, düzenli bir işe sahip olma olasılığını belirli gruplarda önemli ölçüde 
artırmaktadır. Örneğin eğitim ya da ücret açısından dezavantajlı durumda olan genç mezunlar ve göçmenler gibi dezavantajlı gruplar geçici çalışma ile hem deneyim sahibi olmakta hemde sosyal ağlarını genişletebilmektedir. Ancak İsveç, Almanya ya da Birleşik Devletlerin bazı bölgelerinde ise geçici iş ilişkisi ile çalışanların kalıcı bir işe geçiş yapma olasılığı oldukça zordur. Bu nedenle geçici iş ilişkisi ile çalışanlar ya bu istihdam türü içerisinde uzun süre kalmakta, ya farklı özel istihdam bürolarına geçiş yapmakta ya da işsiz kalmaktadırlar (ILO, 2016, ss.188-189).

\section{Grafik 3.5. Geçici Çalışma Oranı, OECD, 2010-2017}

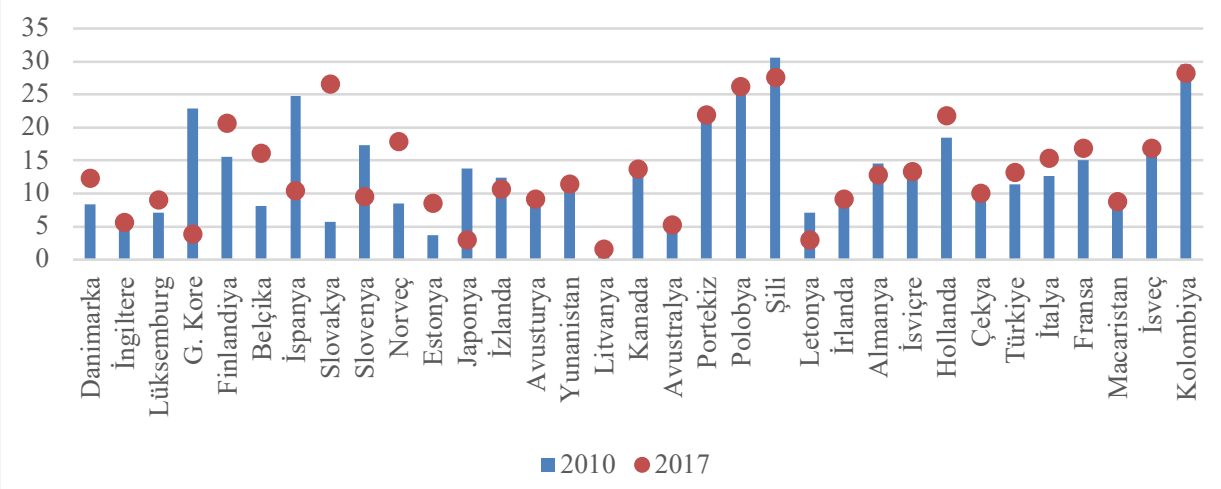

Kaynak: OECD, 2020. [https://data.oecd.org/emp/temporary-employment.htm, Erişim Tarihi: 14.02.2021]

Tüm ücretli çalışanların yüzdesi olarak OECD ülkelerinde geçici istihdam oranı 2010 yılında \%11,8'dir ve 2017 yllına gelindiğinde çok büyük bir değişiklik göstermeyerek \%12 olarak gerçekleşmiştir. 2010 yılında geçici istihdam oranı Güney Kore, Japonya, Litvanya ve Letonya'da \%5 ve altında iken, Kolombiya, Şili, Slovakya ve Polonya'da \%25'in üzerindedir. Geçici istihdamda nispeten istikrara sahip olan tek bölge Kuzey Avrupa'dır. 2010-2017 yılları arasında en önemli artışlar Slovakya, Norveç, Finlandiya, Belçika, Lüksemburg, İtalya ve Hollanda'da kaydedilmiștir. Güney Avrupa ülkeleri arasında İspanya en yüksek orana sahiptir. Doğu Avrupa ülkeleri arasında ise Polonya geçici istihdamın sürekli büyüdüğü tek ülke olup Avrupa'nın geçici istihdam lideri konumundadır.

Ödünç Íş Ílişkisi ve Özel İstihdam Büroları: Ödünç iş ilişkisi bir işverenin hizmet akdi ile istihdam ettiği çalışanın iş görme edimini çalışanın rızasını alarak ve aralarındaki iş ilişskisi son bulmaksızın ekonomik bir karşılık elde ederek veya karşllıksız olarak belirli veya geçici bir süreyle başka bir işverenin emir ve talimatlarıyla gerçekleştirdiği üçlü ilişski olarak tanımlanmaktadır (Usen, 2010, s.170). Ödünç iş ilişkisi ile çalışanların tanımlanması AB ta- 
rafından 2008 yılında kabul edilen 2008/104/EC sayılı yönerge ile gerçekleştirilmiştir. Yönerge ile ödünç iş ilişkisi ile çalışanların çalışma koşullarının iyileștirilmesi, ödünç iş ilişkisine dayalı çalışmanın yaygınlaşması, etkin bir şekilde istihdam oluşturulması ve esnek çalışma modellerinin geliştirilmesi hedeflenmiștir. Direktifin belkemiği ise beşinci maddede öngörülen eşitlik ilkesidir (Usen, 2010, s.176).

Özel istihdam büroları aracılı̆̆ı istihdamda ise, çalışanlar bir işletme tarafından (özel istihdam bürosu) işe alınmakta ve ardından başka bir işletmede (kullanıcı) çalışmalarını veya görevlerini gerçekleştirmektedir. Çoğu ülkede, büro ile çalışan arasında bir iş sözleşmesi ya da ilişkisi ayrıca büro ve kullanıcı işletmeyi arasında da farklı bir anlaşma bulunmaktadır. Çalışanların ücretleri iş görme ediminin gerçekleştirildiği işletme tarafından bürolara gerçekleştirilmekte, çalışanlara ise bürolar tarafından ödenmektedir. Özel istihdam bürosu ile kullanıcı işletme arasında bir istihdam ilişkisi yoktur ancak kullanıcı işletme ve özel istihdam bürosu arasında iş sağlığı ve güvenliği gibi ortak sorumluluk alanları ve yasal zorunluluklar bulunabilir.

Ödünç iş ilişkisi ile çalışmalara ilişkin nicel verilerin, işgücü piyasası düzenlemesinin oldukça karmaşık ve teknik bir alanı olan ve katılımcıların öz değerlendirmesine dayalı anketlerde yaşanılan zorluklar nedeniyle toplanması ve değerlendirilmesi zordur. Bu nedenle bu çalışmada kullanılan veriler farklı ülkeler tarafından kullanılan farklı tanımlamalara dayanmaktadır. Verilerin derlenmesinde yaşanan niceliksel, istatistiksel zorluklara ve zaman zaman tutarsızlıklara rağmen birçok çalışmada, çoğu AB Üye Devletinde ödünç iş ilişkisi ve özel istihdam büroları aracılığıyla çalışan sayısında artış eğilimi olduğu belirtilmektedir (Countouris, vd 2016, ss.23-24).

Dünya İstihdam Konfederasyonu'nun bağlı kuruluşlarından derlediği verilere göre 2013 yılında 40 milyon çalışan, 12 milyon tam gün çalışma günü (veya tam zamanlı eşdeğer) kadar ödünç iş ilişkisi ile çalışmıştır. Ödünç iş ilişkisinin en yoğun kullanıldığı işgücü piyasaları ise ABD (11 milyon çalışan), Çin (10,8 milyon), Avrupa (8,7 milyon) ve Japonya'dır (2,5 milyon). 2010 yll Avrupa Çalışma Koşulları Araștırması'na göre Arnavutluk, Finlandiya, Almanya, Macaristan, İtalya, Malta, Karadağ ve Türkiye'de ödünç iş ilişkisi ile çalışma istihdamın \%1'inden azdır. Kıbrıs, İrlanda, İspanya ve Portekiz gibi ekonomik krizden olumsuz etkilenen ülkelerde ödünç iş ilişkisi kullanımında azalma görülürken, sanayinin işgücü piyasasında varlığını güçlendirdiği eski geçiş ülkelerinde yükselme trendi görülmektedir. 2012 yllı Avrupa İşgücü Anketi verileri, 15-24 yaşlarındaki gençlerin ödünç iş ilişkisi kurma oranının $(\% 2,9) 25-54$ yaş grubundakilerin $(\% 1,3)$ iki katından fazla olduğunu göstermektedir. Sanayi içerisinde ödünç iş ilişkisi en çok nitelik gerektirmeyen işlerde ve fabrika ve makine operatörleri tarafından kullanılmaktadır. Ayrıca düşük vasıflı çalışanlar arasında ödünç iş ilişkisi ile çalışma oranı $(\% 1,8)$, yüksek vasıflı çalışanların $(\% 0,8)$ iki katından daha fazladır (ILO, 2016, s.90). 


\section{İş ve Aile Yaşamı Uyumlaştırma Politikaları Bakımından Esnek Çalışma Düzenlemeleri}

Bilgi ve iletişim teknolojileri, demografi ve yaşam biçimlerindeki değişimler iş ve aile yaşamı arasında bir denge sağlama sorununu da beraberinde getirmiștir. Yaşanan değişimlerle bireyler yaşam süresi boyunca cinsiyete göre farklılık gösteren birçok rol üstlenmişlerdir. Sahip olunan enerji ile birden fazla rolün aynı zaman diliminde yerine getirilme gerekliliği ise iş ve aile yaşamı arasındaki çatışmanın temelini oluşturmaktadır (Doğrul ve Tekeli, 2010, s.12). İş ve aile yaşamının uyumlaştırması bağlamında kullanılan esnek çalışma düzenlemeleri ile iş ve aile yaşamı arasında denge sağlanması ve bireyin üstlendiği roller arasındaki çatışmanın minimum seviyede olması amaçlanmaktadır. Analık izni, babalık izni, ebeveyn izni, evlat edinme izni, bakım izni ve kariyer izni bu amaçla uygulanan esnek çalışma düzenlemelerindendir.

Analık İzni: Annelik koruması temel bir insan hakkı ve kapsamlı iş-aile politikalarının vazgeçilmez bir unsurudur. Anne ve çocuk sağlığının geliştirilmesi ve işyerinde kadınlara karşı ayrımcılığın önlenmesi çok önemlidir. Annelik koruma mevzuatının amacı kadınların sağlık yönünden veya maddi açıdan önyargısı olmaksızın çalışma hayatları boyunca üreme ve üretken olma rolleri ile istihdamda eşit firsat ve muamele görmelerini başarılı bir şekilde birleștirilmesini sağlamaktır. Anneliğin korunması, annelerin ve bebeklerinin sağlık ve refahlarına katkıda bulunur. Böylelikle bebek ve anne ölümlerinin azaltılması, sağlık durumlarının iyileștirilmesi de dâhil olmak üzere önemli kalkınma hedeflerine ulaşılmasını sağlar. 1948 tarihli İnsan Hakları Evrensel Bildirisi (UDHR), annelik ve çocukluk döneminin sosyal güvencenin yanı sıra özel bakım ve yardım alma hakkına sahip olduğunu belirtmektedir. Ayrıca 1992 tarihli 92/85/EEC sayllı Konsey Yönergesinde gebe, yeni doğum yapmış ve emziren kadınların sağlık ve güvenliklerini koruma hedefi bulunmaktadır. ILO tarafından 2000 yılında imzalanan 183 sayılı Anneliğin Korunmasına ilişkin Sözleşmede doğum iznini açılayan uluslararası hukuki belgelerden biridir. Bu sözleșmede hamile ve yakın zamanda doğum yapmış olan kadınlar için koruyucu önlemler ile bu kişilerin sağlık ve güvenlik tehlikelerine maruz kalmasının önlenmesi, ücretli doğum izni ve emzirme izinlerine hak kazanma, anne ve çocuk sağlığı bakımı, işe alma ve ișten çıkarmanın yanı sıra doğum izninden sonra işe geri dönme garantisi dâhil olmak üzere istihdam ve meslekte ayrımcılığa karşı korunmayı sağlayan hükümler bulunmaktadır ILO, 2014, ss.1-2).

Gerek AB'nin 92/85/EC sayılı Konsey Yönergesinde gerekse ILO 183 sayılı Anneliğin Korunmasına ilişkin Sözleşmesi'ne göre hamile ve yeni doğum yapmış kadın çalışanlara doğumdan önce ve sonra belirli sürelerle izin verilmesi gerekliliği bulunmaktadır. Bu kapsamda analık izini kadın çalışanlara 
doğum öncesi ve doğum sonrasında gerek tıbbi gerekse çocuk bakımı, emzirme, vb. sebeplerle verilen izin olup bu iznin belirli bir kısmı zorunludur. Örneğin bahsi geçen $\mathrm{AB}$ yönergesinde kadın çalışanların doğumdan önce veya sonra en az 14 hafta süreli analık izni hakları söz konusudur. Doğum öncesinde ve/veya sonrasında bu sürenin iki haftasını kullanmak zorunludur. 183 sayılı ILO sözleşmesinde de doğum izni süresi minimum 14 hafta olarak belirlenmiştir. Ayrıca 191 sayılı ek tavsiye kararında bu sürenin 18 haftaya çıkarılması hedeflenmektedir. 183 sayılı ILO sözleşmesine göre anne ve çocuğun sağlığının korunması amacıyla analık izninin doğumdan sonraki 6 haftası devlet tarafından ulusal düzeyde ve işverenlerin temsilci örgütleri tarafından aksi kararlaştırılmadıkça zorunlu izin süresidir. Genel olarak dünya genelindeki 185 ülkenin \%53'ünde analık izni en az 14 haftadır ve bu ülkelerin 42'sinde ise 18 hafta ve üzerinde iken \%32'sinde 12 ila 13 hafta arasında, \%15'inde ise 12 haftadan daha kısadır (ILO, 2014, s.9).

Babalık İzni- Ebeveyn İzni - Evlat Edinme İzni: Analık iznine ek olarak yeni doğan ve küçük çocukların bakımı için ailenin diğer bireylerine izin sağlanması, bir çalışanın iş ve aile yaşamını uzlaştırma kabiliyeti açısından önemlidir. Bu izin türü babalık izni, ebeveyn izni ve evlat edinme iznini içerir.

Babalık izni, anneye yardımcı olmak ve çocuğun bakımı için doğumdan hemen sonra babaya tanınan kısa bir izin süresidir. Amacı emzirmenin desteklenmesi ve doğum sürecinden sonra anneye yardımcı olunması, yeni doğanın yanı sıra varsa diğer çocukların bakımını ve ev- aile ile ilgili diğer sorumlulukların paylaşımını desteklemektir. Evde ve işyerinde toplumsal cinsiyet eşitliği için olumlu etkilere sahip olan babalık izni aynı zamanda ebeveynlik rolü ve genel düşünce kalıplarında ve algıda değișiklik oluşturabilmektedir (ILO, 2014, s.52). Babalık izni ile ilgili herhangi ILO standardı bulunmamaktadır. Ancak insana yakışır işlerin temelinde iş-aile uzlaşma tedbirlerinin hem erkekler hem de kadınlar için geçerli olduğu kabul edilmiştir. Bu karar ile hükümetlerin daha iyi bir iş ve aile sorumlulukları dengesi kurabilmesi için erkeklerin babalık ve/veya ebeveyn izinlerini kullanmasına yönelik teşvikler ve politikalar geliştirmesi gerekmektedir. Babalık izni hakları 167 dünya ülkesinin en az 79'unun ulusal mevzuatında bulunmakla birlikte gelişmiş ekonomiler, Afrika, Doğu Avrupa ve Orta Asya ülkelerinde oldukça yaygındır. Babalık izni süresi ülkeden ülkeye farklılık göstermektedir. Örneğin Tunus'ta bir gün olan babalık izni İzlanda'da 90 gün, Slovenya ve Finlandiya'da ise 54 iş gününe kadar değişmektedir. Dünya ülkelerinin \%53'ünde yasal olarak babalık izni verilmemektedir. Bu ülkelerin \%21'inde (Arjantin, Kazakistan, Yunanistan, Fas ve Tanzanya) babalık izin süresi bir haftadan az, \%15'inde (Benin, Bosna-Hersek, Letonya, Filipinler ve Ekvator) 7 ila 10 gün arası, \%8'inde (Azerbaycan, Fransa, Kenya ve Venezuela) 11-15 gün arasıdır. Gelişmiş ülkeler arasında sadece beş ülkede (Finlandiya, İzlanda, Litvanya, Portekiz ve Slovenya) iki haftadan uzun süre babalık izni kullanılmaktadır (ILO, 2014, ss.52-55). 
Ebeveyn izni, annelik veya babalık izni dışında çocuğun bakımı için daha uzun bir izin süresi olup genellikle ebeveynlerden birinin veya her ikisinin de kullanabildiği bir izin türüdür. Genel olarak ebeveyn izni, doğum izni süresinden daha uzundur. Ebeveyn izni ile ilgili herhangi bir ILO sözleşmesi bulunmamaktadır, ancak 183 sayılı Anneliğin Korunması Sözleşmesine ilave olarak 191 sayılı Tavsiye kararı ve 156 sayılı Aile Sorumlulukları Sözleşmesine ilave 165 sayılı Tavsiye Kararları ebeveyn izni ile ilgili hükümler içermektedir. Bu Tavsiye Kararlarına göre, doğum izninden sonra olmak üzere istihdam şartları korunarak ebeveyne izin verilmelidir. Benzer şekilde 96/34/EC sayılı Ebeveyn İznine Dair Çerçeve Anlaşmaya İlişkin Konsey Yönergesinde bir çocuğun doğumu ve evlat edinilmesi halinde belirli bir yaşa gelene ( 8 yıla kadar ve en az 3 ay boyunca) kadar bakımını sağlamak amacıyla erkek ve kadın çalışanlar için ebeveyn izni verilir denilmektedir. Ebeveyn izni ülkeden ülkeye nitelik, ücret, süre, kullanımda olası esneklikler, bakılacak çocuğun yaşı ve ebeveynler arasında aktarılabilirlik açısından değişmektedir. Bazı ülkelerde uzun ebeveyn izni küçük çocukların anne-baba tarafından bakımının sağlanmasını destekleme aracıdır, özellikle küçük çocuklara yönelik olarak bu tür hizmetlerin nispeten pahalı olabileceği çocuk bakım hizmetlerine olan ihtiyacı azaltmaktadır. Bununla birlikte erkeklere göre kadınların daha uzun süre ebeveyn izni kullanması, kadınların işgücü piyasasındaki duruşlarını zayıflatabilmekte hem işgücü hem de aile ve ev sorumluluklarına ilişkin iş bölümünde cinsiyet eşitsizliğini artırabilmektedir. Toplam 169 dünya ülkesinin 66'sında ebeveyn izni hükümleri bulunmaktadır. Gelişmiş ekonomilerin hemen hemen tamamında ebeveyn izni bulunurken İsviçre'de ebeveyn izni hükümleri bulunmamaktadır. Estonya'da anne veya babaya çocuğunu 3 yaşına kadar bakabilmek için ücretsiz ebeveyn izni verilir. Belçika ve Birleşik Krallık'ta, her ebeveynin bağımsız bir ebeveyn izin süresi hakkı vardır. Bu süre Belçika'da sabit ücret üzerinden ödenen dört ay iken Birleşik Krallık'ta 13 ücretsiz haftadır (ILO, 2014, ss.60-64).

Evlat edinme izni ise, ebeveynlerin evlatlık edindikleri çocuklarına bakım yapmaları için zaman sağlamak amaçlı bir izindir. Bu izin evlat edinen ebeveynlerin aileye gelen çocuğa uyum sağlamasına yardımcı olmaktadır. ILO 183 sayılı Anneliğin Korunması Sözleșmesine ilave 191 sayılı Tavsiye kararında belirtildiği üzere doğum izni hükümleri, evlat edinmeye izin veren üye devletlerdeki evlat edinen ebeveynler için de mevcuttur. Bazı ülkelerde evlat edinme izni doğum izni veya doğum izni hükümlerine benzer ya da aynı şekilde kabul edilerek yürürlüğe girmiştir. Örneğin Senegal ve İngiltere'de annelik için sağlanan haklar ve izinler evlat edinme durumunda da kullanılabilir. Brezilya'da evlatlık edinen anneler biyolojik anneler ile aynı haklara sahiptir. Avustralya'da, evlat edinen ebeveynler biyolojik ebeveyn ile aynı ebeveyn izni alır. Birçok ülkede evlat edinen ebeveynlere sağlanan izin hakkı, biyolojik annelere doğum öncesi verilen izinin ortadan kalkması nedeniyle, biyolojik ebeveynlere göre daha kısadır. Ebeveyn izni hakkındaki 96/34/EC 
sayılı AB Direktifine göre bir çocuğun evlat edinilmesi durumunda erkek ve kadın çalışan ebeveynlere en az üç ay izin hakkı vermesi hükmü yer almaktadır. Evlat edinen babaların evlat edinme izinleri ebeveyn izni kapsamında değerlendirilebilmektedir. ILO 191 sayılı Tavsiye Kararı'na göre her iki ebeveynin de bir çocuğu evlat edinmesi gerekir ki bu da bazı ülkelerde geçerlidir. Örneğin İzlanda'da her bir ebeveyn çocuğun evlat edinilmesi durumunda birbirinden bağımsız ve üç aya kadar devredilemeyen annelik/babalık izni hakkına sahiptir ve ayrıca ek üç ay ebeveynlerden biri tarafından alınabileceği gibi kendi aralarında bölünebilir. Yeni Zelanda'da evlat edinen ebeveynlerin hem annelik hem de babalık izni hakları vardır. Bazı ülkelerde evlat edinilen çocuğun yaşı izin süresini etkilemektedir. Örneğin Slovenya'da evlat edinen ebeveynler eğer 4 yaşından küçük bir çocuğu evlat edinmiş iseler 150 günlük ücretli izin, 4 ila 10 yaş arası bir çocuğu evlat edinmiş iseler 120 güne ücretli izine hak kazanırlar. Letonya'da evlat edinilen çocuğun 3 yaşına kadar olması durumunda evlat edinen ailede bir ebeveyn on gün izin kullanabilir iken evlat edinilen çocuğun 3 yaşına kadar olması durumunda evlat edinene ebeveyn altı ay izin kullanabilir (ILO, 2014, ss.69-70).

Bakım İzni - Evde Bakım İzni: Bakım izni, ILO 183 sayılı Anneliğin Korunması Sözleşmesinde yer alan düzenlemeye göre doğum izninin bitiminin ardından hamilelik ve veya doğumdan kaynaklanan ve tıbbi, raporlar belgelenen rahatsızlıkların oluşması durumunda kadın çalışana verilen ek izini ifade etmektedir (Limoncuoğlu, 2010, s.20). Evde bakım izni ise ebeveyn iznini takip eden ve genellikle en az bir ebeveyn tarafından kullanılan çocuğun iki ya da üç yaşına kadar evde bakımını sağlamak için istihdam güvencesi bulunmadığı durumlarda kullanılan izindir. Evde bakım izni annelik izni, babalık izni ve ebeveyn izninden daha az yaygındır ve OECD ülkelerinin çok az bir kısmında uygulanmaktadır (OECD, 2018b).

Kariyer İzni: Kariyer izni çalışanların bir işyerinde belirli bir süre çalıştıktan sonra genellikle belirli bir amacı gerçekleştirmek amacıyla kullandıkları izindir (Limoncuoğlu, 2010, s.20). Kariyer molası olarak da adlandırılan kariyer izni genellikle akademisyenler tarafından kişisel ve mesleki gelişimi artırmak amacıyla kullanılan ücretli bir izin türüdür. Üniversitede çalışan bir akademisyenin belirli bir süre çalışmasının ardından kitap yazma amacıyla izin alması bir kariyer izni örneğidir. Zahorski (1994) çalışmasına göre kariyer molası rutinleșen iş ve görevlerden uzaklaşmayı sağlamaktadır. Kariyer molası izni günümüzde kullanılan izin türlerinden oldukça uzun olup kullanımı yaygın değildir. Rutin işlerin oluşturduğu stres faktörü ortadan kalkarak bu şekilde yenilenme firsatı sunar (Davidson vd., 2010, s.2). 


\section{İşletme ve Çalışan Açısından Esnek Çalışma Düzenlemeleri}

Esnek çalışma düzenlemeleri ile ilgili literatürdeki ampirik kanıtlar esnek çaıışmanın işletmeleri olumsuz makro ekonomik koşullar karşısında ortaya çıkan yeni durumlara daha kolay uyum sağlayarak sayısal esneklik elde etmelerini, taleplerdeki dönemsellik nedeniyle dalgalanmalara ve mali kısitlamalara karşılık verme amacıyla kullanıldığını göstermektedir.

Bazı işletmeler talep dalgalanmaları ve olumsuz șokların sonucu olarak herhangi bir potansiyel ekonomik küçülmede temel işçilerini tam anlamıyla korumak için esnek çalışma düzenlemelerinden faydalanmaktadır. Böylece bu düzenlemeler işletmelere talepteki dalgalanmalara uyum sağlaması sürecinde bir tampon görevi görmektedir. Ancak yoğunluğun olmadığı dönemlerde üretimin yeniden planlanması veya çalışma saatlerinin azaltılması gibi düzenlemelerin de kullanıldığı görülmektedir.

Bir önceki bölümde açılanan esnek çalışma düzenlemelerinin her birinin hem işveren hem çalışana sağladığı avantajlar ve dezavantajlar bulunmaktadır. Örneğin kısmi süreli çalışma özellikle hizmet sektöründe önemli bir motivasyondur. Nitekim belirli ülkelerde perakende sektöründe uzun çalışma saatlerine bağlı olarak işletmelerin vardiyalarda yeterli personel bulundurabilmek için istihdam oluşturmaya teşvik etmiş ve kısmi süreli istihdam oranlarında artışlar meydana gelmiştir. Bununla birlikte kısmi süreli çalışma ile tam zamanlı çalışma imkânı olmayan çalışanlara istihdam fırsatı sunulabilmekte, işgücü piyasasında ilk defa yer alacak özellikle kadın ve genç bireyler için kolaylaştırıcı bir rol oynayabilmekte, iş ve aile hayatı arasında daha iyi bir denge sağlayabilme ve esnek iş planlaması yapabilme imkânı sağlamaktadır (ILO, 2016, s.159).

İşverenler açısından ise işgücü maliyetlerini azaltıcı bir strateji olarak kullanılması sağladığı avantajlardan olmakla birlikte işgücünün yönetim ve denetim zorluğu, uzun dönemde işgücünün niteliğinde ve çalışma veriminde düşüş yaşanması ise dezavantajları arasındadır. Tam zamanlı çalışanlara göre daha kısa süre ve daha düşük saatlik ücretlere bağlı olarak daha düşük gelir elde etme, kısmi süreli çalışmanın bir seçim değil zorunluluk olması, kariyer firsatlarında sınırlı ilerleme imkânı, eğitim firsatlarından ve sosyal güvenceden (emeklilik, sağlık gibi) yararlanabilme zorlukları, iş yoğunluğu nedeniyle daha kısa sürede tam zamanlı iş yüküne maruz kalma ve düzensiz çalışma saatleri ise çalışanlar bakımından dezavantaj olarak görülmektedir (ILO, 2004, s.4; Koç ve Görücü, 2011, ss.161-164).

Çağrı üzerine çalışma ile bir taraftan işveren sadece işin yoğun olduğu zaman dilimlerinde çalışan istihdam ederek maksimum verimlilik ve fayda sağlamakta, normal şartlar altında istihdam edemeyeceği yüksek nitelikli işgücünden faydalanabilme imkânı yakalamaktadır. Öte yandan işyerinde pasif işsizlik ortadan kalkmaktadır ve mali yönden ciddi avantajlar elde edebilmektedir. Çalışanın her an işveren tarafından verilen görevi yerine getirmek 
için hazır durumda olması bakımından eleştirilen çağrı üzerine çalışma, koruyucu yasal düzenlemeler yapılmasıyla çalışma zamanı ve süresi hakkında öngörü sahibi olunmasını ve çalışanın işleri arasında düzenlemeler yapabilmesini sağlayacaktır. Çalışma saatlerindeki değişkenlik sosyal güvenlik kapsamında yer almak için gerekli eşik değerleri sağlamada zorluklara neden olabilir. Değişken ve öngörülemeyen çalışma programlarına sahip çalışanlar arasında sendikal bağlılık daha az olmakla birlikte, bu tür çalışma düzenlemelerini azaltması nedeniyle toplu pazarlık çalışma koşullarının belirlenmesinde önemli bir etkiye sahiptir.

Tele çalışma kısmi süreli ve çağrı üzerine çalışmanın sağladığı avantajlara sahip olmakla birlikte bazı durumlarda (bakım yükümlülüğü, engellilik, vb.) işgücü piyasasına katılım noktasında tek yol olabilmektedir. Bu nedenle hem bakım yükümlülüklerini yerine getirebilme hem de işgücünün daha verimli hale gelerek performansta artış sağlayabilmektedir. Ancak sosyal izolasyonu nedeniyle stresli hale gelmesi, takım çalışmasının zorlaştırması, statü kaybı endişesi, terfi sorunları, firsatların kısıtlılığı, iş sağlı̆̆ı ve güvenliği açısından korunmanın zorlaşması, sendikasızlaşma ile iş hukuku ve sosyal güvenliğin koruyuculuğundan uzaklaşılması (Baruch, 2000, s.38; Dambrin, 2004, s.363; Noyan, 2007, s.119), çalışan bakımından teknolojiye erişim zorluğu, çalışanların performansının izlenmesi ve ölçülmesinde yaşanan güçlükler, organizasyon stratejileri (Perez, Sanchez, Carnicer, 2002, s.776) ise işletme bakımından dezavantajlar arasında sayılabilmektedir.

Esnek zamanlı çalışma modeli çalışana biyolojik temposuna uygun çalışma süresini belirleyebilme imkânı sağlayarak çalışanların etkinlik ve verimliliklerini artırabilmektedir. Çalışanın işe geç gelmesinden kaynaklanan fazla çalışma yapma zorunluluğunun ortadan kalkması ve böylece daha fazla ücret ödemesi yapılmaması ise işverene sağladığı avantajlardan iken bu tür bir çalışma düzenini kurma maliyeti, işletmenin daha uzun bir süre açık kalması sebebiyle işletme giderlerinin yükselmesi, çalışanların daha kısa bir zaman ve belirli olmayan saatlerde işletmede bulunması sebebiyle organizasyonel sorunların ortaya çıkması ise olumsuzlukları arasında sayılabilir (Eyrenci, 1994, ss.165-166, Tokol, 2011, s.138).

İşletmelerin taleplerinde meydana gelen değişikliklere cevap vermesi, geçici olarak işten ayrılan çalışanların yerine istihdam sağlaması veya yeni işe alınan çalışanlar ile açı uçlu bir sözleşme yapmadan önce değerlendirebilmesi imkânı sağlayan belirli süreli çalışma çalışanların işgücü piyasasına girişini kolaylaştırma ya da işgücü piyasasına kazandırılmasını sağlama, iş deneyimini artırma beceri düzeylerini geliştirme, sosyal ve profesyonel ağlarını genişletme imkânı sunmaktadır. Ancak kısa süreli (belirli bir görev, süre, iş) istihdam beklentisi nedeniyle yüksek istihdam güvencesizliği riski de taşımaktadır, ayrıca gelir bakımından aynı tür iş için belirsiz süreli bir çalışana göre daha düşük ücret elde edilmektedir. Belirli süreli çalışma kısa sürelerle 
istihdam sağlaması nedeniyle sosyal güvenlik prim gereksinimleri bakımından da gereksinimlerin karşılanmasında yetersizliklere neden olarak düşük miktarlı işsizlik ve emeklilik yardımlarına neden olur (ILO, 2016, s.225).

Esnek çalışma düzenlemeleri çalışanlara iş tecrübesi kazanma firsatı ve bunun yanı sıra işgücü piyasasından ayrılmış olanlara yeniden istihdam edilme fırsatı da sunabilir. Özel istihdam bürosu aracılığı ile istihdam da dâhil olmak üzere geçici istihdam hem işe özgü hem de genel olarak becerilerin geliştirilmesi, işgücü piyasasına alışma, iş etiği geliştirme ve sosyal ve profesyonel ağların genişletilmesi için firsatlar sunabilir. Bir işverenin bir çalışanı geçici bir pozisyonda işe alması, çalışanın işyeri taleplerine uyum sağlayıp sağlamadığını ve bu nedenle işletme veya kuruluşlarında sürekli veya tam zamanlı bir pozisyon için kabul edilip edilemeyeceğinin değerlendirmesini sağlayabilir. Özel istihdam büroları potansiyel çalışan yelpazesini genişletmekte ve daha standartlaştırılmış yöntemler kullanarak çalışanlarını takip etmektedir. Genellikle herhangi bir iş bulmakta zorluk çekecek bireyleri işe almaktadırlar.

Geçici çalışma, özellikle çocuk sahibi ebeveynler veya diğer bakmakla yükümlü oldukları kişileri olan çalışanlar ve aynı zamanda eğitim veya mesleki eğitim ile işlerini birleştirmek isteyen çalışanlar için işgücüne katılımda alternatif sunan bir çalışma şeklidir. Örneğin başlangıçta eğitim ya da ücret açısından dezavantajlı olan genç mezunlar ve göçmenler gibi belirli etki grupları için bu farklılıklar oldukça güçlüdür. Ancak geçici çalışma yapanların birçoğunun genç ve deneyimsiz olmaları, deneyim eksiklikleri, iş sağlığı ve güvenliği açısından önemli birer risk faktörüdür. Sınırlı pazarlık gücüne sahip olmaları, çalışma koşullarını değiştirmelerini ya da güvenlik hususunda taleplerini artırmaları ve takip etmeleri üzerinde olumsuz etkiye sahiptir. Yine geçici çalışma durumunda, bazı yasal hükümler çalışanların (örneğin proje veya görev temelli işlerde) sosyal güvence istihkaklarında kesintilere neden olabilir veya sosyal güvence kapsamı altına alınma olasılıkları düşük olabilir (ILO, 2016, ss.186-217;234-244).

İş ve aile yaşamının uyumlaştırılması kapsamında annelik için yeterli bir koruma sağlanması ailelere, işçilere, işverenlere ve bir bütün olarak topluma fayda sağlamanın yanı sıra sosyal ve ekonomik kalkınmaya da yardımcı olmaktadır. İș ve aile yaşamı arasındaki dengeyi sağlamayı ele alan politikalar, iş ve aile sorumlulukları ile özel hayatta karşılaşılan cinsiyet eşitsizlikleri arasındaki çatışmayı çözmeyi amaçlamaktadır. Hamilelik sırasında ve sonrasında hem annenin hem de yeni doğan bebeğin sağlık ve güvenlik tehlikelerine maruz kalmasını önlemek, kadınların üreme ve üretken rollerini başarılı bir şekilde birleştirmelerini sağlamak, üreme rolleri nedeniyle işte eşit olmayan muameleyi önlemek, kadınlar ve erkekler arasında firsat ve muamele eşitliği sağlamak iş ve aile yaşamını uyumlaştırma politikalarının ana hedefleri arasında yer almaktadır. Bu amaç doğrultusunda ücretli doğum izni hem annenin hem yeni doğan bebeğin yeni hayata uyumuna imkân sağlayacak 
hem de kadının işgücünün istihdam içerisinde kalmasını destekleyecektir. Annenin yanı sıra çocuk bakımı konusunda babanın da bebeğin/çocuğun bakımında sorumluluk alabilmesi için babalık, ebeveyn ve bakım izinleri aile yaşamı içerisindeki toplumsal cinsiyet eşitliğini destekleyici uygulamalardır.

\section{Sonuç ve Değerlendirme}

Yaşanan gelişmelerin ve değişen koşulların iş dünyasına getirdiği yenilikler, küresel tedarik zincirleri aracılı̆̆ıyla dünya çapındaki işletmelerin birbirine bağlılığı, imalatın gelişmekte olan ülkelere kayması ve dünya çapında hizmet sektörünün büyümesi, kadınların işgücündeki rolünün artması, uluslararası göçün devam etmesi, çalışanların iş ve kişisel yaşam organizasyonlarında esnekliğe daha fazla ihtiyaç duyulmasına neden olmuștur. 1970'lerden itibaren çok sayıda ülke işgücü piyasası esnekliğini arttırmak ve istihdam büyümesini canlandırmak amacıyla işgücü piyasalarında süregelen ve sınırlandırıcı etkileri bulunan koşullarda gevşemeler oluşturmuş, işgücü piyasasında katılık oluşturan uygulamalardan nispeten vazgeçilerek daha esnek bir yapı benimsenmeye başlamıștır.

İşletmeler mevsimsellik, işletme döngüsündeki değișiklikler, işletmeler arası rekabet veya dişsal şoklar sonucu mal ve hizmet taleplerinde dalgalanmalara maruz kalmaktadır. Bu nedenle işletmeler esneklik sağlama arayışına girmişler ve işgücü piyasasında daralmaların yaşandığı, taleplerin düștüğü zamanlarda ve içinde bulundukları mevcut koşullar doğrultusunda iş organizasyonunda ve personel istihdam politikalarında değişiklik yapmak istemişlerdir. Nitekim Covid-19 pandemisi hem ekonomik hem de toplum sağlığ bakımından yaşanan en büyük krizlerden biridir. Pandemi sürecinde işgücünün büyük bir bölümü - işletmelerin imkanları elvermesi durumunda - esnek çalışma modelleri ile çalışmaya devam etmiştir. Bu çalışmada işgücü piyasalarında uygulamada yer bulan çeşitli esnek çalışma düzenlemeleri istihdam şekilleri, çalışma süreleri ve iş ve aile yaşamı uyumlaştırma politikaları bakımından üç başlık altında incelenmiştir. Esnek çalışmanın, çalışma koşullarının hemen hemen tüm yönleri üzerinde, çalışma düzenlemesinin türüne, çalışan profiline ve ayrıca işletme, endüstri ve ülke koşullarına bağlı olarak çeşitli etkileri bulunabilir.

İstihdam düzenlemeleri bakımından esnek çalışma ülke mevzuatlarının yanı sıra, faaliyet gösterilen endüstri, genellikle işletmelerin kapasitesi, ticari sırları, rekabetçi işletmelerin uygulamaları, işgücünün sahip olduğu nitelik ve beceri seviyeleri gibi belirli özelliklere göre uygulamada farklılıklar gösterebilmektedir. İşletmelerin olumsuz makroekonomik koşullar karşında sayısal esneklik elde etmelerini, talepteki dönemsellik nedeniyle dalgalanmalara karşılık verilebilmelerini ve mali kısıtlılıklar karşısında destekleyici olarak kullanılarak herhangi bir potansiyel ekonomik küçülmede işletmenin esas çalışanlarını tam anlamıyla korumak amacıyla tercih edebilmektedirler. 
Çalışma programlarında esnekliğe sahip olmak, çalışanların kendi iş-aile dengesi sağlamaları üzerinde olumlu bir etki olușturur. Özellikle, çalıșma günü içinde işe başlama ve bitirme zamanlarını belirleme ve molalar düzenleme özgürlüğüne sahip olmak, çalışma saatlerinin ailevi yükümlülüklerine ve sosyal sorumlulukları yerine getirebilmeye imkân sağlayacağı algısını artırmaktadır.

Bakmakla yükümlü olduğu kişileri olan çalışanlar, özellikle çocukları veya diğer bakım sorumlulukları olan kadınlar için ve ayrıca işi eğitim veya mesleki eğitimle birleştirmek isteyen çalışanlar için işgücüne alternatif bir katılım biçimini temsil eder. Bu nedenle esnek çalışma, çalışanın kendi seçiminin sonucu olması ve işin kaliteli olması durumunda istihdamın ve işgücüne katılımın artırılmasına ve daha iyi bir iş-yaşam dengesinin sağlanmasına katkıda bulunabilir, genel olarak iş performansını, verimi ve yaşam memnuniyetini artırabilir.

Özellikle, tüm çalışanların -hem kadın hem de erkek- günlük olarak kişisel yaşamları için yeterli zamana sahip olmalarını sağlamak amacıyla çalışma süresi önlemlerinin iş-yaşam dengesini kolaylaştıracak şekilde tasarlanması gerekmektedir. Bireylerin çalışma programlarını kişisel yükümlülüklerini karşılayacak şekilde esnek bir şekilde ayarlamalarına izin vererek, "aile dostu" çalışma süresi işçilerin ve ailelerinin yanı sıra bir bütün olarak topluma fayda sağlayacaktır.

\section{KAYNAKÇA}

Alakeson, V. (2012). The price of motherhood: Women and part-time work. London: Resolution Foundation.

Alp, E., (2012). Türk iş̧ hukukunda evde çalış̧ma. Yüksek Lisans Tezi, Sakarya Üniversitesi, Sosyal Bilimler Enstitüsü, Sakarya.

Baruch, Y. (2000). Teleworking: Benefits and pitfalls as perceived by professionals and managers. New Technology, Work and Employment, 15(1), 3449.

Blanpain, R., Pennings, F., Süral, N. (2006). Flexibilisation and modernisation of the Turkish labour market. Kluwer Law International, The Netherlands.

Cazes, S., ve Nesperova, A., (2007). Flexicurity: A relevant approach in Central and Eastern Europe. Geneva: ILO Publications.

Centel, T., (1992). Kısmi çalış̧a İ̀stanbul: Kazancı Kitap Ticaret A.Ş.

Countouris, N., Deakin, S., Freedland, M., Koukiadaki, A., Prassl, J., (2016). Report on temporary employment agencies and temporary agency work. Genova: ILO,

Dambrin, C. (2004). How does telework influence the manager employee relationship?" International Journal of Human Resources Development and Management, 4, 4, 2004.

Davidson, O. B., Eden, D., Westman, M., Cohen-Charash, Y., Hammer, L. B., Kluger, A. N., Krausz, M., Maslach, C., O'Driscoll, M., Perrewé, P. L., Quick, J. C., 
Rosenblatt, Z., and Spector, P. E. (2010). Sabbatical leave: Who gains and how much?". Journal of Applied Psychology, 95, 953-964. doi: $10.1037 / \mathrm{a} 0020068$.

Del Boca, D., (2002). The effect of child care and part time opportunities on participation and fertility decisions in Italy. Journal of Population Economics, 15(3), 549-573.

Di Martino, V. ve Wirth, L. (1990). Telework: A new way of working and living. International Labour Review, 129, 529-554.

Doğrul, B.Ş. ve Tekeli, S. (2010). İş ve yaşam dengesinin sağlanmasında esnek çalişma. Sosyal ve Beșeri Bilimler Dergisi, 2(2), 11-18.

Ekonomi, M. (1994). Türk iş hukukunda esnekleşme gereği. Çalışma Hayatında Esneklik Semineri. İzmir: Yaşar Eğitim ve Kültür Vakfı Yayını.

Emirmahmutoğlu, M. (2015). Esneklik açısından evde çalışma ilişkileri. Yüksek Lisans Tezi, Bahçeşehir Üniversitesi, Sosyal Bilimler Enstitüsü, İstanbul.

Eryiğit, S. (2011). Esnek üretim, esnek organizasyon, esnek çalışma. Kamu-İş, Işs Hukuku ve Íktisat Dergisi, 5(4), İnternet Adresi; http://www.kamuis.org.tr/pdf/5411.pdf , Erişim Tarihi: 05.04.2018.

Eurofound (2007). Working time developments 2006, (Mark Carley) Dublin 2007. https://www.eurofound.europa.eu/observatories/eurwork/comparative-information/working-time-developments-2006

Eurofound (2007). Varieties offlexicurity: Reflections on key elements of flexibility and security. Background Paper, Dublin.

Eurofound (2017). Sixth European working conditions survey - Overview report (2017 update). Luxembourg: Publications Office of the European Union.

Eurostat (2020). Labour force statistics. https://ec.europa.eu/eurostat/home Erişim Tarihi: 12.12.2020.

Eyck, K. V., (2003). Flexibilizing employment: An overview", SEED Working Paper No. 41, Geneva: ILO Publishing, International Labour Office.

Eyrenci, Ö. (1994). Çalışma hayatında esneklik (Türkiye'de çalışma sürelerinin esnekleștirilmesi), Tükelmat A.Ș.

Gash, V. (2008). Preference or constraint? Part-Time workers' transitions in Denmark, France and the United Kingdom. Work, Employment and Society, 22(4), 655-674.

ILO, (2004). "What is Part Time Work?" Conditions of Work and Employment Programme, Information Sheet, No. WT-4. Geneva: ILO.

ILO, (2011). "Working Time in The Twenty-First Century" Conditions of Work and Employment Programme, Discussion Report, No. TMEWTA/2011. Geneva: ILO.

ILO, (2013). Working Condition Law Report 2012: A Global Review. Geneva: ILO.

ILO (2014). Maternity and Paternity at Work : Law and Practice Across the World. Geneva: ILO.

ILO, (2016). Non-Standart Employment Around the World Understanding Challenges, Shaping Prospects. Geneva: ILO.

ILO, (2019). Guide to Developing Balanced Working Time Arrangements. Geneva: ILO. 
Jain, H., ve Hassard, J., (2014). Precarious work: Definitions, workers affected and osh consequences. Bilbao, Spain: EU-OSHA. https://oshwiki.eu/wiki /Precarious_work:_definitions,_workers_affected_and_OSH_consequences (Erişim Tarihi: 15.06.2018).

Kalleberg, A., L., (2000). Nonstandard employment relations: Part-Time, temporary and contract. Annual Review of Sociology, 26, 341-365.

Kantarcl, T., ve Van Soest, A. (2008). Gradual retirement: Preferences and limitations. De Economist, 156(2), 113-144. http://doi.org/10.1007/s10645008-9086-1.

Karadeniz, O. (2011). Türkiye'de Atipik çalışan kadınlar ve yaygın sosyal güvencesizlik. Calışma ve Toplum, 2011/2, 83-127.

Koç, M., ve Görücü İ., (2011). 4857 sayılı iş kanununa göre kısmi çalışma uygulaması ve sonuçları. Çalışma ve Toplum, 28(1), 149-178.

Limoncuoğlu, A., (2010). Türk iş hukuku ve sosyal güvenlik hukukunda güvenceli esneklik. İzmir: Limoncuoğlu Ltd.

McMenamin, T. (2007). Time to work: Recent trends in shift work and flexible schedules. Monthly Labor Review, 130(12), 3-15.

Miani C., Hoorens, S., (2014). Parents at work men and women participating in the labour force. European Commission, Cambridge: Rand Europe.

OECD (2018). Part time employment rate. https://data.oecd.org/emp/part-timeemployment-rate.htm Erişim Tarihi: 11.04.2018

OECD, (2018b). Family database, key characteristic of parental leave systems. http://www.oecd.org/els/soc/PF2_1_Parental leave systems.pdf Erişim Tarihi: 02.07.2018.

OECD, (2020). Labour force statistics. www.data.oecd.org Erişim tarihi: 12.12.2020.

Ogura, K., (2010). Research study on diversification of working places and working hours. Japan Labour Review, 7(2), 97-114.

Perez, P., Sanchez, A.M., Carnicer, M.P. de Luis, (2002). Benefits and barriers of telework: Perception differences of human resources managers according to company's operations strategy. Technovation, 22 (2002) 775783.

Pollert, A., (1988). The 'Flexible Firm': Fixation or fact?. Work, Employment and Society, 2(3), 281-316.

Riedmann, A., Gyes, G.v., Román, A., Kerkhofs, M., Bechmann, S., (2010). European Company Survey 2009. Luxembourg: Office for Official Publications of the European Communities.

Rodgers, G. (2007). Labour market flexibility and decent work. Newyork: DESA Working Paper No. 47 ST/ESA/2007/DWP/47.

Selby C., F.Wilson, W.Korte, J.Millard, W.Carter, (2004). Flexible working handbook, Draft 1.0, 2001, s. 3. 4 BT, "Flexible Working”. London: British Telecommunicators (BT).

Standing, G., (1999). Global labour flexibility: Seeking distributive justice. Palgrave- MacMillan Publ. 
Stredwick, J., Steve, A., (2002). Flexible working practices: Techniques and innovations. London: Chartered Institute of Personnel and Development.

Tan, G., (2007). Atipik iş sözleşmelerinden evde çalışma ve tele çalışma. Yüksek Lisans Tezi, Başkent Üniversitesi, Sosyal Bilimler Enstitüsü, Ankara.

Tangian, A.. (2005). Monitoring flexicurity policies in the EU with dedicated composite indicators. WSI Working Papers 137, The Institute of Economic and Social Research (WSI), Hans-Böckler-Foundation.

Taşoğlu ve Limoncuoğlu, (2010). 4857 sayılı kanun kapsamında esnek çalışma. Sosyal ve Beşeri Bilimler Dergisi, 2(2), 77

TİSK (1994). Çalışma hayatında esneklik. Ankara: TİSK İnceleme Yayınları No: 10. Tokol, A., (2011). Endüstri ilişskileri ve yeni gelişmeler. Bursa: Dora Yayınevi.

Tomev, L. (2009). Working time in the European Union: Bulgaria. European Working Conditions Observatory. http://www.eurofound.europa.eu/ewco/studies/tn0803046s/bg0803049q.htm. Erişim Tarihi:11.04.2018.

Treu, T., (1992). Labour flexibilty in Europe. International Labour Review, ILO, 131(3), 497-511.

Tuncay, C. (1995). Esnekleşmenin değişik boyutları. Çalışma Hayatında 21. Yüzyılın Yeni Ufukları içinde (s.207-227) Yayın No: 227, İstanbul: MESS.

Usen, Ş. (2010). 2008/104/EC sayılı ödünç iş ilişkisine ilişkin Avrupa Birliği yönergesinin getirdiği yeni düzenlemelerin Türkiye açısından değerlendirilmesi. Çalışma ve Toplum, 26(3), 169-190.

Yavuz, A. (1995). Çalışma hayatında esnek çalışmanın ortaya çıkışı, esnekliğin nedenleri ve esneklik türleri. Cimento İșveren Dergisi, 9(1), 25-36.

Yazar Aslan, B. (2019). OECD ülkelerinde güvenceli esneklik uygulamaları: Karşılaştırmalı panel veri analizi. Doktora Tezi, Gazi Üniversitesi, Sosyal Bilimler Üniversitesi, Ankara.

Wilthagen, T. ve F. Tros (2004). The concept of 'flexicurity': A new approach to regulating employment in the labour market. TRANSFER - European Review of Labour and Research, 10(2), 166-86. 